\title{
Matrix permeability of reservoir rocks, Ngatamariki geothermal field, Taupo Volcanic Zone, New Zealand
}

\author{
J. L. Cant, P. A. Siratovich, J. W. Cole, M. C. Villeneuve* and B. M. Kennedy
}

\author{
${ }^{*}$ Correspondence: marlene. \\ villeneuve@canterbury.ac.nz \\ Department of Geological \\ Sciences, University \\ of Canterbury, Private Bag \\ 4800, Christchurch 8140, \\ New Zealand
}

\begin{abstract}
The Taupo Volcanic Zone (TVZ) hosts 23 geothermal fields, seven of which are currently utilised for power generation. Ngatamariki geothermal field (NGF) is one of the latest geothermal power generation developments in New Zealand (commissioned in 2013), located approximately $15 \mathrm{~km}$ north of Taupo. Samples of reservoir rocks were taken from the Tahorakuri Formation and Ngatamariki Intrusive Complex, from five wells at the NGF at depths ranging from 1354 to $3284 \mathrm{~m}$. The samples were categorised according to whether their microstructure was pore or microfracture dominated. Image analysis of thin sections impregnated with an epoxy fluorescent dye was used to characterise and quantify the porosity structures and their physical properties were measured in the laboratory. Our results show that the physical properties of the samples correspond to the relative dominance of microfractures compared to pores. Microfracture-dominated samples have low connected porosity and permeability, and the permeability decreases sharply in response to increasing confining pressure. The pore-dominated samples have high connected porosity and permeability, and lower permeability decrease in response to increasing confining pressure. Samples with both microfractures and pores have a wide range of porosity and relatively high permeability that is moderately sensitive to confining pressure. A general trend of decreasing connected porosity and permeability associated with increasing dry bulk density and sonic velocity occurs with depth; however, variations in these parameters are more closely related to changes in lithology and processes such as dissolution and secondary veining and re-crystallisation. This study provides the first broad matrix permeability characterisation of rocks from depth at Ngatamariki, providing inputs for modelling of the geothermal system. We conclude that the complex response of permeability to confining pressure is in part due to the intricate dissolution, veining, and recrystallization textures of many of these rocks that lead to a wide variety of pore shapes and sizes. While the laboratory results are relevant only to similar rocks in the Taupo Volcanic Zone, the relationships they highlight are applicable to other geothermal fields, as well as rock mechanic applications to, for example, aspects of volcanology, landslide stabilisation, mining, and tunnelling at depth.
\end{abstract}

Keywords: Pores, Volcaniclastic, Confining pressure, Microfractures, Connected porosity 


\section{Background}

New Zealand relies on geothermal energy to generate approximately $16.5 \%$ of its electricity (MBIE 2017). The generation portfolio was increased in 2013 with the addition of 82 MWe generation capacity at the Ngatamariki geothermal field (NGF) (Fig. 1). Understanding the nature and behaviour of the geothermal reservoir at Ngatamariki is of upmost importance for the efficiency and longevity of the geothermal resource. Two key properties that control reservoir behaviour are porosity and permeability of the reservoir rocks (Jafari and Babadagli 2011). Porosity is the measure of void volume (empty space) and permeability indicates how easily a fluid can pass through a medium (Guéguen and Palciauskas 1994). Because porosity does not indicate the shape, size, and distribution of the voids, it provides limited information about the ability for a fluid to flow through the rock. Porosity includes both connected porosity and unconnected porosity. Unconnected porosity refers to void spaces that are not interconnected with the rest of the void network and, therefore, cannot be accessed by fluids. Connected (or effective) porosity refers to void spaces that are interconnected and can, therefore, contribute to permeability. This study focuses only on connected porosity. Many studies have described the control of the primary rock textures on permeability, with large differences between intrusive, volcanic, and sedimentary rocks (e.g., Géraud 1994; Heap et al. 2015, 2017b; Ruddy et al. 1989; Farrell and Healy 2017). Alteration, dissolution, and mineralisation associated with hydrothermal fluids also affect connected porosity (e.g., Wyering et al. 2014). Permeability as defined by Henry Darcy in the mid-1800s applies to non-turbulent (Darcian) flow (Glassley 2010). It is scale dependent with distinct differences between macro- (metre scale fractures) and micro (matrix)-scale permeability

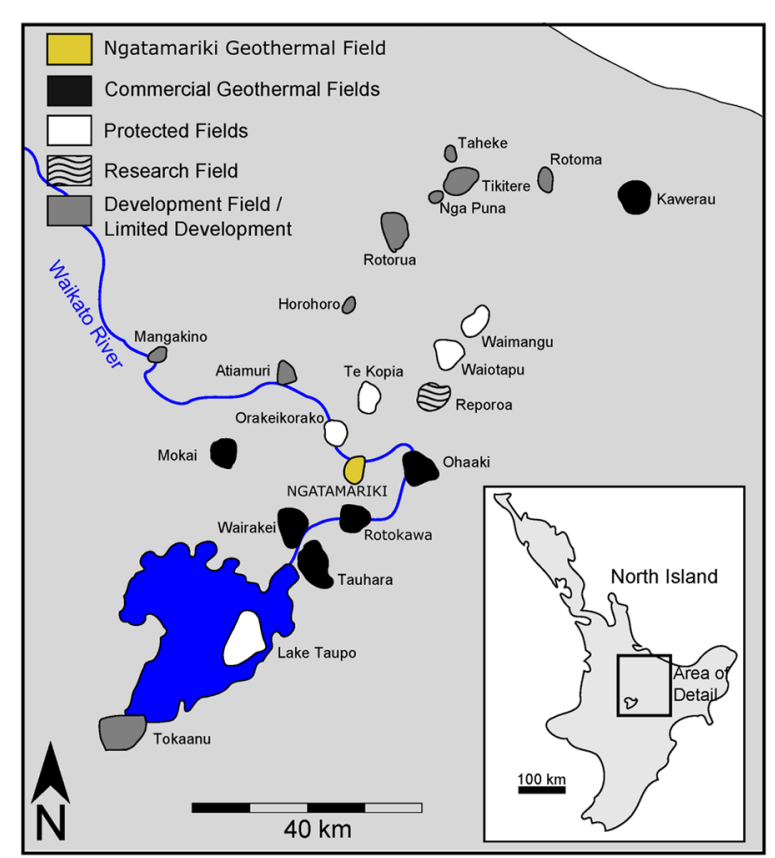

Fig. 1 Known geothermal fields within the TVZ as defined by the resistivity boundaries given by Bibby et al. (1995) (Modified from Boseley et al. 2012) 
(Heap and Kennedy 2016) and can be partially attributed to the random distribution of void structures throughout a rock mass (Glassley 2010).

A common approach to modelling a geothermal system is to assume dual porosity/ permeability, where two interactive continua, macro-fracture, and matrix permeability are assumed to have their own unique properties (Jafari and Babadagli 2011). Natural macro-fractures within a geothermal system, resulting from unconformities, cooling joints, and tectonic stress discontinuities, strongly control fluid flow due to their high permeability (Murphy et al. 2004), and generally control the permeability in geothermal systems (Jafari and Babadagli 2011). Testing of macro-fracture permeability is usually done in situ with injection flow rate tests used to identify areas of high permeability associated with fractured zones (Watson 2013). In this study, we focus on sample scale (i.e., matrix) properties of recovered drill core. This provides the second component of rock mass permeability, which, when combined with in-situ testing, forms the basis for permeability inputs for reservoir modelling.

In this paper, we present laboratory tests of rocks from the Tahorakuri Formation and Ngatamariki Intrusive Complex (NIC), from five wells at depths of 1354-3284 m. We made measurements of porosity, dry bulk density, ultrasonic velocity (saturated and dry), and permeability (at a range of confining pressures). We also present an assessment of the sensitivity of the permeability of the tested lithologies to confining stress. In particular, we focus on the type and shape of the pores and microfractures (Siratovich 2014; Lamur et al. 2017) and how they affect the fluid flow properties of rocks from NGF. Finally, we explore the relationships between burial diagenesis, hydrothermal alteration, and physical properties. An understanding of the reservoir rock's physical properties can help with field exploration and operation, as well as provide guidance to numerical models that can guide future field optimisation.

\section{Geological setting}

The Taupo Volcanic Zone (TVZ) is a rifted arc in the centre of the North Island of New Zealand, related to the subduction of the Pacific plate below the Australian plate at the Hikurangi margin. The geology, volcanology, and structure of the TVZ have been thoroughly described elsewhere by authors such as Wilson et al. (1995) and more recently with a geothermal perspective by authors such as Wilson and Rowland (2016). NGF is situated in the central part of the TVZ (Fig. 1) and is operated as a geothermal power generation site by Mercury NZ Limited. Twelve deep boreholes have been drilled between 1980 and 2016 with the most recent (NM12) in 2014. There are currently four production and five injection wells along with 34 monitoring wells, used to observe shallow, intermediate, and deep aquifer fluid and pressure trends. A small number of these wells also provide monitoring of the separation between NGF and the nearby protected Orakei-Korako geothermal area.

The subsurface stratigraphy encountered at NGF (Fig. 2; Table 1) has been described by Bignall (2009), Boseley et al. (2012) and Chambefort et al. (2014). The Tahorakuri Formation is the unit of primary interest in this study for several reasons. It is one of the significant reservoir rocks at NGF (e.g., Coutts 2013), and spot cores recovered during drilling cover a wide range of depths within this unit, allowing investigation of the changes in physical properties with depth. The Tahorakuri Formation is a sequence 


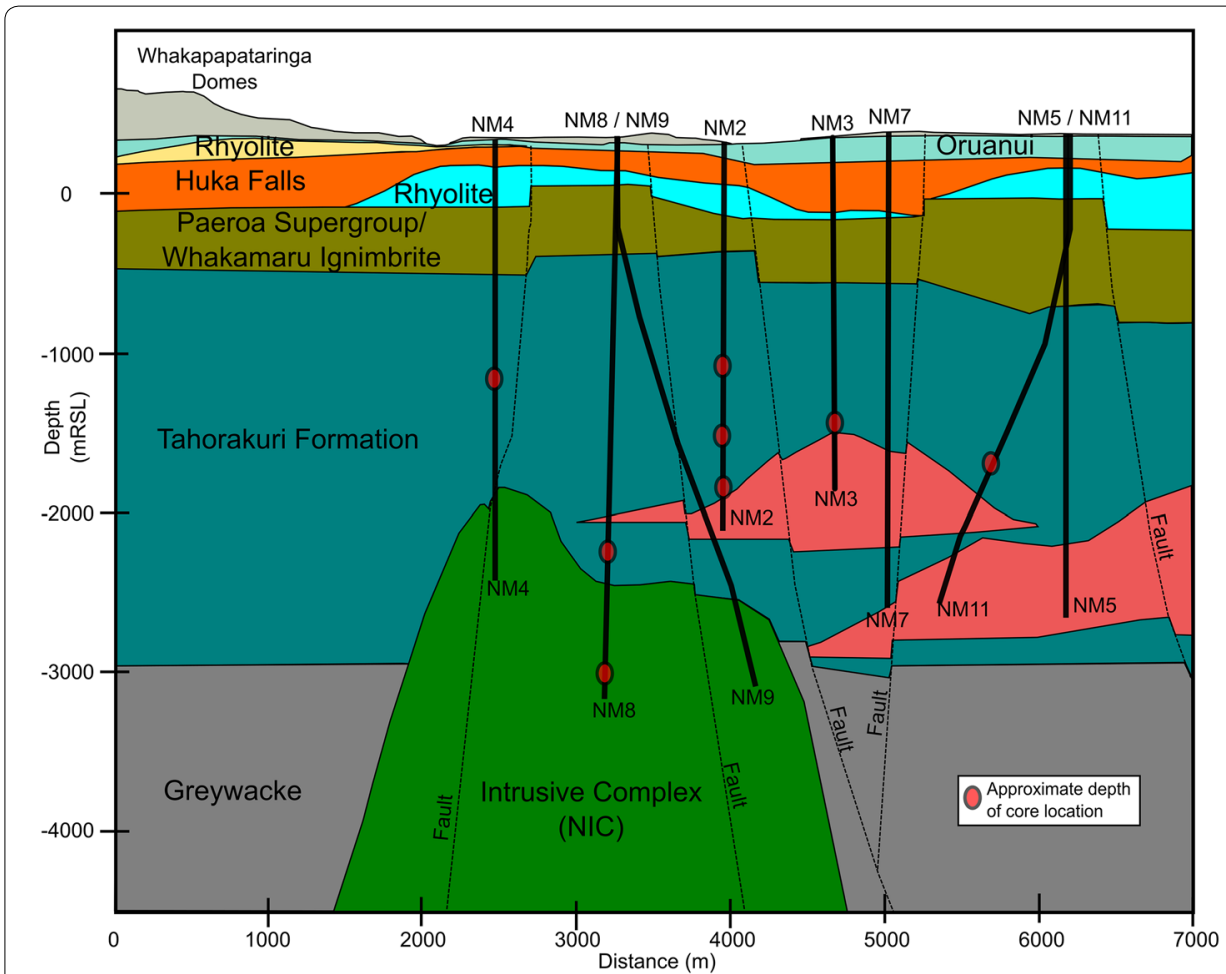

Fig. 2 Geological cross section of the Ngatamariki geothermal field from the NW to the SE with boreholes NM1-NM11 projected (after Bignall 2009; Boseley et al. 2012; Chambefort et al. 2014 and Mercury NZ Limited internal document)

of deposits between the Whakamaru Group ignimbrites and the Torlesse greywacke basement. At NGF, the Tahorakuri Formation comprises a thick pyroclastic sequence ( 1000-1500 m thick) of primary tuffs, volcaniclastic (reworked) tuffs, and welded ignimbrites, overlain by sediments and tuffs in the northern and central part of the field (Chambefort et al. 2014). In the north to northwest of the field a quartz-phyric tonalite intrusion was encountered in three boreholes. This study also incorporates measurements of samples from this intrusion and the Tahorakuri volcaniclastic tuffs and ignimbrites. Dating of the Tahorakuri Formation (Eastwood 2013; Chambefort et al. 2014) indicates the unit was deposited over 1.22 Ma. Figure 2 shows locations of cores used in this study.

\section{Methods}

All rock preparation, measurement, and analysis were carried out in the rock mechanics laboratories, at the Department of Geological Sciences, University of Canterbury (Cant 2015). Samples were taken from core supplied by Mercury NZ Limited and Tauhara North No. 2 Trust. A drill press was used to extract $25-20 \mathrm{~mm}$ diameter cylinders from the core using a diamond tipped coring bit. The cylinders were all oriented parallel to the long axis of the core samples, making them approximately vertical within the stratigraphic column. A small piece of each cylinder was removed for thin section preparation for petrophysical analysis and void structure investigation. The cylinders were cut for a length-to-diameter ratio between 1:1.8 and 1:2.2, and ground flat for parallel ends as 
Table 1 Subsurface lithology of Ngatamariki from wells NM1-7, as described by Bignall (2009)

\begin{tabular}{|c|c|c|}
\hline \multicolumn{3}{|c|}{ Ngatamariki stratigraphy } \\
\hline Formation name & Thickness (m) & Lithological description \\
\hline Orakonui Fm & $0-10$ & Pumice breccia, with common volcanic lithics, quartz and minor feldspar \\
\hline Orunanui Fm & $15-85$ & $\begin{array}{l}\text { Cream to pinkish vitric-lithic tuff, with vesicular pumice and lava lithics, } \\
\text { plus quartz, feldspar and rare pyroxene crystal fragments }\end{array}$ \\
\hline Huka falls Fm & $>70-285$ & $\begin{array}{l}\text { Coarse to medium grained sandstone, minor gravel (laminated lacustrine } \\
\text { sediments) }\end{array}$ \\
\hline Waiora Fm & $0-10$ & $\begin{array}{l}\text { An upper level interval of Waiora Formation, comprises pumice-rich vitric } \\
\text { tuff, with volcanic lithics, quartz, rare biotite and pyroxene crystals }\end{array}$ \\
\hline Rhyolite lava & $115-315$ & $\begin{array}{l}\text { Glassy rhyolite lava, with perlitic textures, phenocrysts are quartz, feldspar, } \\
\text { pyroxene and magnetite }\end{array}$ \\
\hline Waiora Fm & $0-240$ & $\begin{array}{l}\text { A lower interval of Waiora Formation, comprising pumice-rich vitreous } \\
\text { tuff, intercalated with crystal tuff, tuffaceous coarse sandstone and tuf- } \\
\text { faceous siltstone }\end{array}$ \\
\hline Wairakei ignimbrite & $100-200$ & $\begin{array}{l}\text { Crystal-lithic tuff/breccia, with abundant quartz, minor feldspar, rare bio- } \\
\text { tite and pyroxene, minor volcanic lithics and pumice, in a fine ash }\end{array}$ \\
\hline Rhyolite lava & $0-285$ & $\begin{array}{l}\text { Hard porphyritic quartz-rich rhyolite lava with phenocrysts of quartz, } \\
\text { minor feldspar, and minor ferromagnesian minerals }\end{array}$ \\
\hline Tahorakuri Fm & $460-700$ & $\begin{array}{l}\text { White to pale grey lithic tuff/breccia intercalated with fine sediments. In } \\
\text { NM6 it is intercalated with } 310 \text { m of andesite lavas and breccias (tuffs } \\
\text { and sediments) }\end{array}$ \\
\hline Tahorakuri Fm & $>200-840$ & $\begin{array}{l}\text { Pale grey, lithic tuff/breccia containing dark grey/brown lava, rhyolite } \\
\text { pumice greywacke-argillite and sandstone clasts in a silty matrix (Akat- } \\
\text { erewa ignimbrite) }\end{array}$ \\
\hline Tahorakuri Fm & $>830$ & $\begin{array}{l}\text { Pale grey porphyritic feldspar, pyroxene and amphibole andesite lava and } \\
\text { breccia (andesite lava, breccia) }\end{array}$ \\
\hline Torlesse greywacke & Undefined & $\begin{array}{l}\text { Pale grey to grey, massive meta-sandstone which lack obvious bedding, } \\
\text { quartz veins }\end{array}$ \\
\hline
\end{tabular}

recommended by Ulusay and Hudson (2007) to allow for future unconfined compressive strength (UCS) testing. After coring and grinding the cylinders, they were placed in an ultrasonic bath with distilled water to clean and remove loose fractured material or clays formed during core drilling and grinding, then oven dried.

\section{Thin section analysis}

From the 21 samples collected, 17 were prepared for thin sections. Fluorescent epoxy was impregnated under vacuum into the sample, which was then polished. The microstructure was characterised using a Nikon Eclipse 80i epifluorescence microscope. The epifluorescent microscope uses a high-pressure mercury lamp that radiates ultraviolet light, which interacts with the fluorescent epoxy resin impregnated within the sample. Areas where the resin has accumulated (pores, vugs, fractures, etc.), glow under the light emitted by the mercury bulb (as in Heap et al. 2014). The advantage of this method of impregnation is the fluorescent dye only accumulates in the connected void spaces. The Nikon Eclipse 80i also has a standard microscope bulb, so features can be compared in fluorescent light and plane-polarised light. This allows areas that have been identified as void spaces in fluorescent light to be confirmed using plane-polarised light.

The thin sections were petrographically assessed to identify the primary and secondary mineralogy and textures in the samples to identify rock type and microstructure. 
Photomicrograph maps of the fluorescing thin sections were taken for analysis of the two-dimensional microstructure. The computer program Autostitch was used to stitch 1620 individual photographs of the thin sections into one large image. Open source software ImageJ was then used to identify and isolate areas in which the fluorescent dye had aggregated (as in Heap et al. 2014).

To analyse the microstructure in the rocks of NGF, binary photomicrograph maps were created for each sample to identify areas of connected porosity. The resultant image (Fig. 3) has completely isolated the connected void spaces from the groundmass. From this image, quantitative analysis can be performed on the connected porosity. Using the analytical functions in ImageJ, the connected porosity was calculated on all binary thin section images as a percentage of the total area of the binary image that was black (void space).

Two types of micro-porosity were observed in the binary images: microfractures and pores. To differentiate the two forms of porosity, the definition applied by Heap et al. (2014) was used, where microfractures have a length-to-width ratio (aspect ratio) typically above 1:100 and pores typically range from 1:1 (perfectly circular) to 1:10 (oval).

Pore analysis was performed in ImageJ to ascertain the aspect ratio, circularity and roundness of the pores. The circularity is a measure how smooth the edges of the pore are, whereas the roundness is a measure of how close to the shape of a circle the pore is. Roundness is the reciprocal of aspect ratio, with additional scaling factors. A minimum pore area of $0.0002 \mathrm{~mm}^{2}$ was used during all pore analysis. This precision is controlled

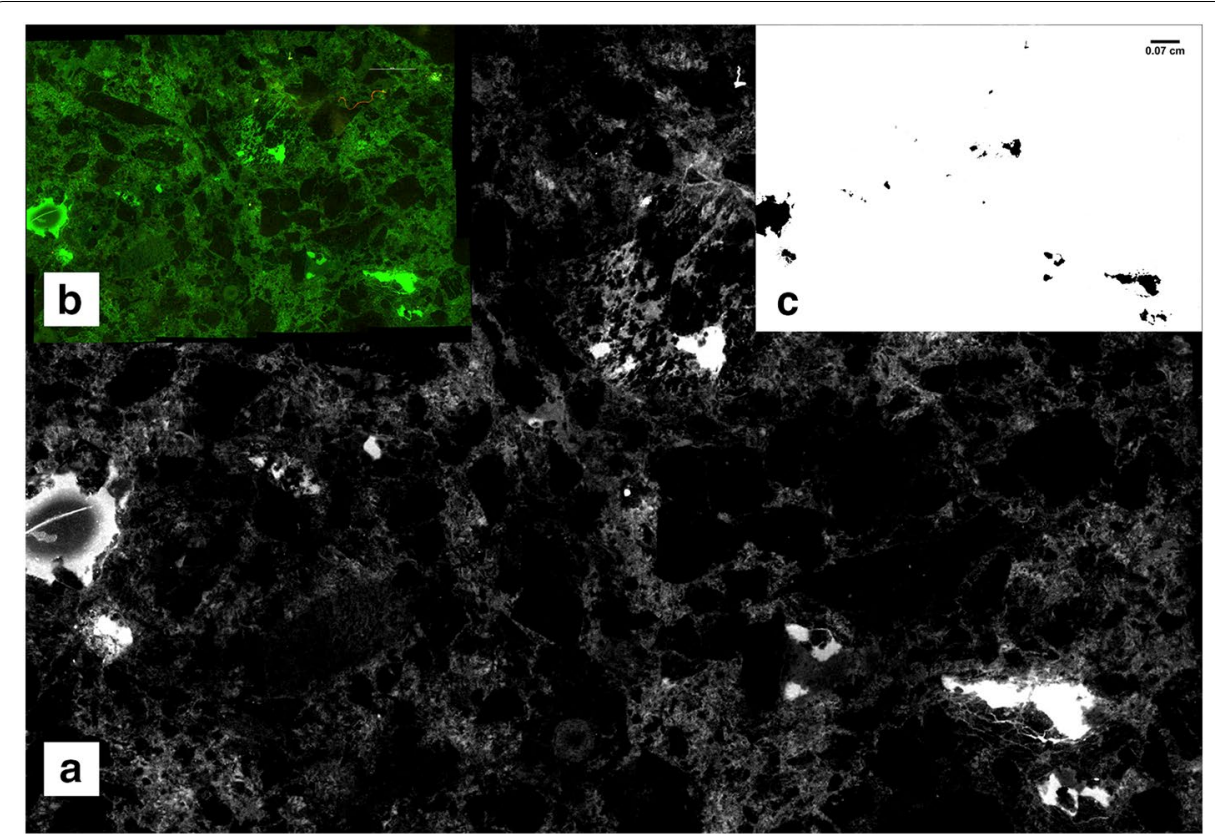

Fig. 3 a Thin section of sample with pore-dominated porosity and only one minor fracture visible; $\mathbf{b}$ thin section under fluorescent light; c TS3 binary image with the connected voids in black and unconnected voids and minerals in white. In the bottom right of the image, there are visibly fewer fractures surrounding the vug in c than in a due to the white intensity selected for the image. If the intensity was set to allow for the microfractures surrounding the vug in c to be visible, several falsely identified "void spaces" in the background would also be identified. While there are small areas of voids that are not identified in the final image, in $\mathbf{c}$, there is a high degree of confidence that all identified void spaces are true pore spaces 
by the quality of the images used. Below this value, the void space resolution becomes poor and no longer provides an adequate representation of the voids they characterise. To analyse the pores, first, they were converted into best fit ellipses to allow ImageJ to perform the quantitative analysis. These ellipses have the same area, orientation, and centroid as the pore they represent. ImageJ then measures the major and minor axis lengths and angles. Henceforth, all reference to the quantitative pore analysis will refer to the measurements performed on the best fit ellipses. The pore parameters were automatically calculated by the ImageJ software using Eqs. 1-4:

$$
\begin{aligned}
& \text { Aspect ratio }=\frac{\text { Long axis }}{\text { Short axis }} \\
& \text { Area }=(\text { Major axis })(\text { Minor axis }) . \\
& \text { Circularity }=4 \pi\left(\frac{\text { Area }}{\text { Perimeter }^{2}}\right) . \\
& \text { Roundness }=4\left(\frac{\text { Area }}{\pi(\text { Major axis })^{2}}\right) .
\end{aligned}
$$

Microfracture surface area was measured using classical stereological techniques outlined by Underwood (1969) and further described by Wu et al. (2000) and Heap et al. (2014). Using the binary images created in ImageJ the number of microfractures intersecting a grid of parallel and perpendicular lines spaced at $0.1 \mathrm{~mm}$ is recorded. The microfracture density per millimeter in each plane is then calculated from the known length and width of the image giving values for $P \|$ (microfractures intersecting parallel lines per millimeter) and $P \perp$ (microfractures intersecting perpendicular lines per millimeter). This allows the calculation of microfracture surface area per unit volume using Eq. 5 (Underwood 1969; Wu et al. 2000):

$$
s_{\mathrm{v}}=\frac{\pi}{2} P \perp+\left(2-\frac{\pi}{2}\right) P \|,
$$

where $s_{\mathrm{v}}=$ surface area per unit volume, $\mathrm{mm}^{2} / \mathrm{mm}^{3} ; P \perp=$ microfracture density for intercepts perpendicular to orientation axis, $\mathrm{mm}^{-1} ; P \|=$ microfracture density for intercepts parallel to orientation axis, $\mathrm{mm}^{-1}$.

Anisotropy of the microfracture intersection distribution was calculated using Eq. 6 (Underwood 1969; Wu et al. 2000):

$$
\Omega_{2,3}=\frac{P \perp-P \|}{P \perp}+\left(\frac{4}{\pi}-1\right) P \|,
$$

where $\Omega_{2,3}=$ anisotropy of microfracture distribution.

\section{Connected porosity, dry bulk density, and ultrasonic wave velocity}

Connected porosity and dry bulk density were determined using the saturation and buoyancy method (Ulusay and Hudson 2007). Axial P (compressional) and S (shear) 
wave velocities were measured using a GCTS (Geotechnical Consulting and Testing Systems) Computer-Aided Ultrasonic Velocity Testing System (CATS ULT-100) device. Piezoelectric transducers within the device are used to measure the arrival time of the compressional and shear waves from which the velocity can be calculated. A loading frame applied a load of $2.7 \mathrm{kN}$ ( $5 \mathrm{MPa}$ axial stress) to the samples to ensure solid contact between the sample and the Piezoelectric transducers. This results in consistent waveforms for all velocity measurements. The applied stress of $5 \mathrm{MPa}$ was selected, such that it did not cause plastic deformation of the extensively altered rock mass, based on the likely strengths of the rocks given in Wyering et al. (2014).

Ultrasonic wave velocity tests were performed on the samples twice, once when the samples were oven dried and again when the samples had been saturated in distilled water under a vacuum. Dry samples were oven dried and stored in a desiccator before testing, while the saturated samples were stored submerged before testing. A total of 144 waveforms were captured for both the dried and saturated samples. First, 72 waveforms were captured in one axial direction and the samples were flipped to capture waveforms in the other direction. The values were then compared and averaged to obtain a representative value for the sample and account for any anisotropy of wave propagation associated with directivity. The waveform velocities were used to calculate dynamic Poisson's ratio and Young's Modulus using Eqs. 7 and 8 (Guéguen and Palciauskas 1994):

$$
\begin{aligned}
& v=\frac{V_{\mathrm{P}}^{2}-2 V_{\mathrm{S}}^{2}}{2\left(V_{\mathrm{P}}^{2}-V_{\mathrm{S}}^{2}\right)}, \\
& E=\frac{\rho V_{\mathrm{S}}^{2}\left(3 V_{\mathrm{P}}^{2}-4 V_{\mathrm{S}}^{2}\right)}{\left(V_{\mathrm{P}}^{2}-V_{\mathrm{S}}^{2}\right)},
\end{aligned}
$$

where $v=$ Poisson's ratio; $V_{\mathrm{p}}=$ compressional P-wave velocity $(\mathrm{m} / \mathrm{s}) ; V_{\mathrm{s}}=$ shear S-wave velocity $(\mathrm{m} / \mathrm{s}) ; E=$ Young's modulus $(\mathrm{Pa}) ; \rho=\operatorname{dry}$ bulk density $\left(\mathrm{kg} / \mathrm{m}^{3}\right)$.

\section{Permeability}

Permeability measurements were conducted using a pulse decay permeameter (Corelab PDP-200) with confining pressure (Fig. 4). The sample was placed inside a Viton tube inside the core holder (testing cell) and a confining pressure ranging from 5 to $65 \mathrm{MPa}$

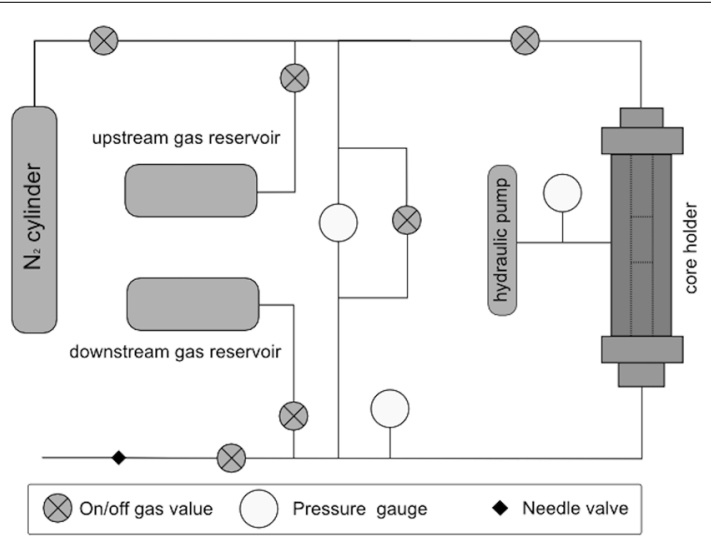

Fig. 4 Schematic diagram of the components of the pulse decay permeameter used for testing 
was applied by a manual hydraulic pump. Pressurised nitrogen was applied to the sample and left to "soak" to allow the sample to equalise to the test pore pressure and temperature. The pore pressure was selected based on the expected permeability of the sample, which was inferred from the connected porosity. The higher the expected permeability (based on porosity measurements), the lower the pore pressure was used to ensure laminar gas flow. The gas valves were shut and the nitrogen gas bled from the downstream side of the core holder until a desired pressure differential was achieved. The bypass was then closed and the pressure differential across the sample was monitored as the pressure equilibrated by the gas traveling through the sample. The gas differential across the sample decays in logarithmic fashion that is recorded by the PDP 200's software.

The calculation for gas permeability according to a modified version of Darcy's law (Brace et al. 1968) is as follows:

$$
k_{\mathrm{gas}}=\left(\frac{2 \eta L}{A}\right)\left(\frac{V_{\mathrm{up}}}{P_{\mathrm{up}}^{2}-P_{\mathrm{down}}^{2}}\right)\left(\frac{\Delta P_{\mathrm{up}}}{\Delta t}\right)
$$

where $k_{\text {gas }}=$ gas permeability; $\eta=$ viscosity of the pore fluid; $L=$ length of the sample; $A=$ cross-sectional area of the sample; $V_{\text {up }}=$ volume of upstream pore pressure circuit; $P_{\text {up }}=$ upstream pore pressure; $P_{\text {down }}=$ downstream pore pressure; $\mathrm{t}=$ time.

Equation 9 is used by the PDP 200's software to calculate the gas permeability of the differential pressure decay curve and results in gas apparent permeability measurements. To determine the true permeability, a Klinkenberg correction is required (Klinkenberg 1941) to account for gas slippage within the sample:

$$
k_{\text {true }}=k_{\text {gas }}\left(1+\frac{b}{P_{\text {mean }}}\right),
$$

where $k_{\text {true }}=$ true permeability; $k_{\text {gas }}=$ gas permeability at a particular pore pressure; $b=$ Klinkenberg slip factor; $P_{\text {mean }}=$ mean pore pressure.

Conducting a Klinkenberg correction requires the gas permeability test to be performed at several different pore pressures. By plotting gas permeability versus $1 / P_{\text {mean, }}$ the true permeability can be taken as the trend line intercept on the permeability axis.

A testing procedure was followed for each sample to achieve an accurate and repeatable result. The test started at the lowest possible confining pressure $(5 \mathrm{MPa})$, where three-to-five apparent gas permeability tests would be measured. The confining pressure would then be increased by $10 \mathrm{MPa}$ and the sample would be left to "soak" for the appropriate amount of time before testing the permeability using the method described above. The soak time varied depending on the permeability of the sample and ranged from $5 \mathrm{~min}$ to up to $24 \mathrm{~h}$. Soak times were established through trial and error. If the sample had not fully equalised the test results showed a non-logarithmic decay, upon which the test was repeated with a longer soak time. This procedure was repeated until the confining pressure reached $65 \mathrm{MPa}$, except for two volcaniclastic samples that were only tested from to $55 \mathrm{MPa}$ due to their low strength as determined by Wyering et al. (2014). 


\section{Lithostatic stress model}

When investigating the effects of burial diagenesis on physical properties, it is important to conduct tests at the conditions from which the samples were taken. This was not possible for the thin section analysis, connected porosity, dry bulk density, and ultrasonic wave velocity, but possible for permeability using the PDP 200. To achieve this, a lithostatic stress model was compiled from the cross section and lithologies, as shown in Fig. 2. Due to the extensional nature of TVZ, $\sigma_{1}$ was assumed to be vertical (Hurst et al. 2002); this allowed the true lithostatic stress to be calculated using Eq. 11:

$$
\sigma^{\prime}=\sigma_{\text {bulk }}-\sigma_{\text {hydro }},
$$

where $\sigma^{\prime}=$ true (effective) lithostatic stress; $\sigma_{\text {bulk }}=$ bulk lithostatic stress; $\sigma_{\text {hydro }}=$ hydrostatic stress.

The bulk lithostatic stress is the combined stress of each overburden unit as applied to each sample, which varies from sample to sample due to differing burial depths and/ or different overlying lithological units. The hydrostatic stress is the total stress applied by the groundwater. The hydrostatic stress is assumed to be equal in all directions and results in a stress that acts against the lithostatic stress. This stress is experienced at pore and fracture boundaries within the rock mass (e.g., Peacock et al. 2017). Due to limited published data on the hydrology of the field, a very simple hydrostatic model was used that assumed a connected water column throughout the field of cold water (to maintain a constant density for calculation). The bulk lithostatic stress applied to any sample by the overlying intact rock is calculated by summing the bulk lithostatic stress for each overlying layer using Eq. 12:

$$
\sigma_{\text {bulk }}=\rho g h,
$$

where $\sigma_{\text {bulk }}=$ stress $(\mathrm{MPa}) ; \rho=$ intact rock dry bulk density $\left(\mathrm{kg} / \mathrm{m}^{3}\right) ; g=$ gravitational force $\left(\mathrm{m} / \mathrm{s}^{2}\right) ; h=$ layer thickness $(\mathrm{m})$.

The hydrostatic stress is calculated using Eq. 12, where $\rho$ is the density of water at $20{ }^{\circ} \mathrm{C}\left(1000 \mathrm{~kg} / \mathrm{m}^{3}\right)$, and $h$ is the depth from which the sample was recovered. The effective lithostatic stress is then the lithostatic stress minus the hydrostatic stress.

\section{Results}

Lithological units

Rock types in the reservoir can be divided into two broad groups: volcaniclastic and intrusive. The Tahorakuri Formation comprises mainly volcaniclastic rocks, while the Ngatamariki Igneous Complex comprises predominantly tonalite.

The volcaniclastic rocks are largely silicic lapilli tuffs with recrystallised pumice clasts and occasional lithics (dominantly $2-5 \mathrm{~mm}$ ) in an ash matrix containing small crystals of alkali feldspar, plagioclase, and quartz (dominantly $0.1-2 \mathrm{~mm}$ ), although all glass has ubiquitously recrystallised (Fig. 5). Shallow samples (Fig. 5a, b) contain recrystallised pumice clasts of quartz and feldspar that in some samples appear rounded, with large pores partially infilled with zeolites, clay minerals, pyrite, and rare epidote. Some of the larger pores are rectangular relict feldspar, which are also variably infilled. In these shallow samples, the matrix is fine-grained quartz and feldspar or locally clay. Intermediate depth (Fig. 5c, d) samples have common epidote and calcite filling large pores locally 


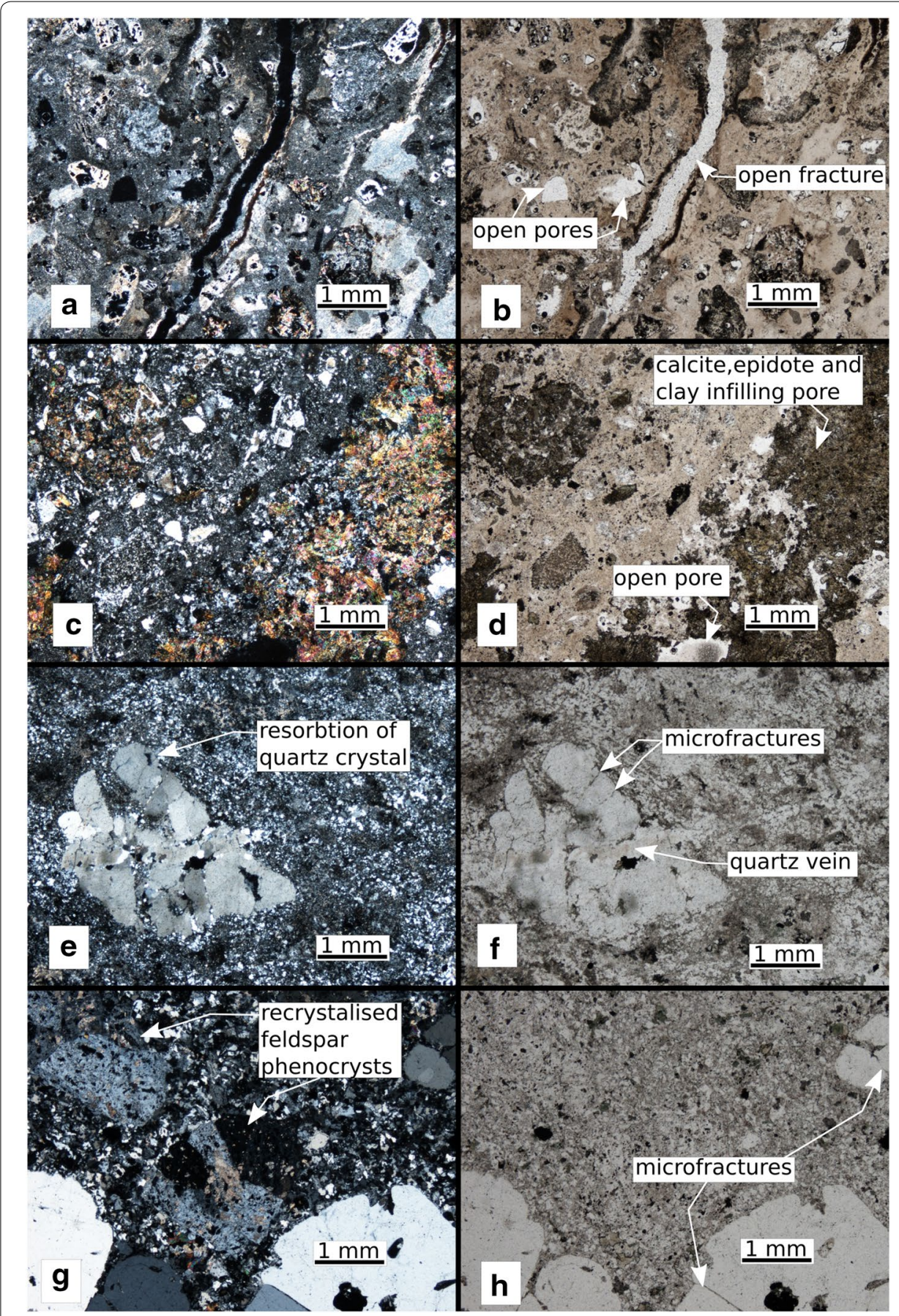

Fig. 5 Cross-polarised (left) and plane-polarised (right) photomicrographs of $\mathbf{a}$, $\mathbf{b}$ shallow-, mixed pore-, and microfracture-dominated lapilli tuff with recrystallised pumice clasts, and partially precipitated microfractures with altered margins (thin section from NM2_1350B_01 Wyering et al. 2014); c, d intermediate depth, pore-dominated lapilli tuff with large pores infilled with epidote and clay, most original textures are no longer visible due to re-crystallisation (thin section from NM11 1.2_01 Wyering et al. 2014); e, f deep, microfracturedominated lapilli tuff showing recrystallization textures, quartz vein, and resorption of quartz crystal in pumice clast (thin section NM8A C1_4_02 from Wyering et al. 2014); $\mathbf{g}, \mathbf{h}$ deep, microfracture-dominated tonalite with quartz and feldspar phenocrysts showing resorption (quartz) and recrystallization (feldspar) (thin section NM8A C2_1_1 from Wyering et al. 2014) 
filled with clay and little evidence of primary volcanic textures except the presence of fragmental and whole feldspar phenocrysts. In deeper (Fig. 5e, f) samples, relict pumice containing larger phenocrysts of quartz have a re-crystallisation fabric reminiscent of fiamme which could suggest welding in an ignimbrite.

The tonalite (Fig. 5g, h) is porphyritic with large quartz ( 40\%) and feldspar ( 60\%). Fractured quartz phenocrysts $(\geq 5 \mathrm{~mm})$ are sub rounded and embayed due to resorption. Plagioclase phenocrysts are generally more euhedral, but largely recrystallised into finer grained feldspar and clay. The fine-grained groundmass $(\sim 0.1 \mathrm{~mm})$ is dominantly quartz and feldspar with minor chlorite and epidote.

\section{Pore and microfracture analysis}

Three distinct styles of microstructure are present in the thin sections: (1) shallow, relatively high connected porosity $(\sim 10-21 \%)$ samples contain variable microstructure with occasional large dissolution pores and partially precipitated microcracks with altered margins (Fig. 5a, b). (2) intermediate depth, with intermediate connected porosity (13-15\%) consisting of large irregular pores, dissolution pores partially filled with secondary crystals with few/no visible microfractures (Fig. 5c, d). Some pores show evidence of pore collapse (crushed pore in bottom right of Fig. 3a, c). (3) deep, relatively low connected porosity samples $(\sim 3-7 \%)$ dominated by microfractures in and around phenocrysts (Fig. 5e, f). The microfractured volcaniclastic samples have no large pores due to complete re-crystallisation and microfractures are frequently filled with secondary mineralization (quartz vein in Fig. 5f). The tonalite is dominated by microfractures associated with large fractured phenocrysts (Fig. $5 \mathrm{~g}, \mathrm{~h}$ ).

For the pore-dominated samples, aspect ratio, pore area, circularity, roundness, and vug porosity were determined (Table 2 ). The pore-dominated thin sections are from NM11 within a depth range of 2083-2087 m. The permeability at the lowest confining pressure (5 $\mathrm{MPa}$ ) was used to compare to the pore analysis, which was conducted at atmospheric pressure. Figure 6 indicates that only circularity correlates with permeability.

For the microfractured samples, microfracture densities were determined and used to calculate the microfracture area per unit volume and anisotropy (Table 3). Microfracture density (area per unit volume) ranged from 2.28 to $31.77 \mathrm{~mm}^{2} / \mathrm{mm}^{3}$ with anisotropy

Table 2 Quantitative analysis of thin sections with vug pore space

\begin{tabular}{lllllll}
\hline Sample ID & $\begin{array}{l}\text { Thin sec- } \\
\text { tion \# }\end{array}$ & $\begin{array}{l}\text { Vug porosity } \\
(\%)\end{array}$ & $\begin{array}{l}\text { Average } \\
\text { circularity }\end{array}$ & $\begin{array}{l}\text { Average } \\
\text { aspect ratio }\end{array}$ & $\begin{array}{l}\text { Maximum } \\
\text { aspect ratio }\end{array}$ & $\begin{array}{l}\text { Average } \\
\text { roundness }\end{array}$ \\
\hline NM11 2083 B & TS1 & 1.2 & 0.41 & 1.99 & 3.94 & 0.56 \\
NM11 2087.4 C & TS3 & 1.6 & 0.46 & 2.05 & 6.96 & 0.57 \\
NM2 2254.7 A & TS4 & 9.5 & 0.32 & 2.10 & 3.78 & 0.53 \\
NM11 2083 C & TS5 & 3.1 & 0.34 & 2.02 & 5.53 & 0.56 \\
NM11 2083.34 A & TS6 & 0.1 & 0.47 & 1.73 & 2.32 & 0.63 \\
NM11 2087.4 D & TS7 & 0.4 & 0.37 & 1.89 & 3.24 & 0.60 \\
NM11 2087.4 A & TS8 & 4.4 & 0.33 & 2.12 & 7.35 & 0.55 \\
NM11 2083 A & TS10 & 1.6 & 0.37 & 2.45 & 7.89 & 0.49 \\
NM11 2087.4 B & TS11 & 1.5 & 0.37 & 2.45 & 7.89 & 0.49 \\
NM8a 2525.5 C & TS12 & 2.4 & 0.39 & 2.32 & 9.78 & 0.51 \\
\hline
\end{tabular}



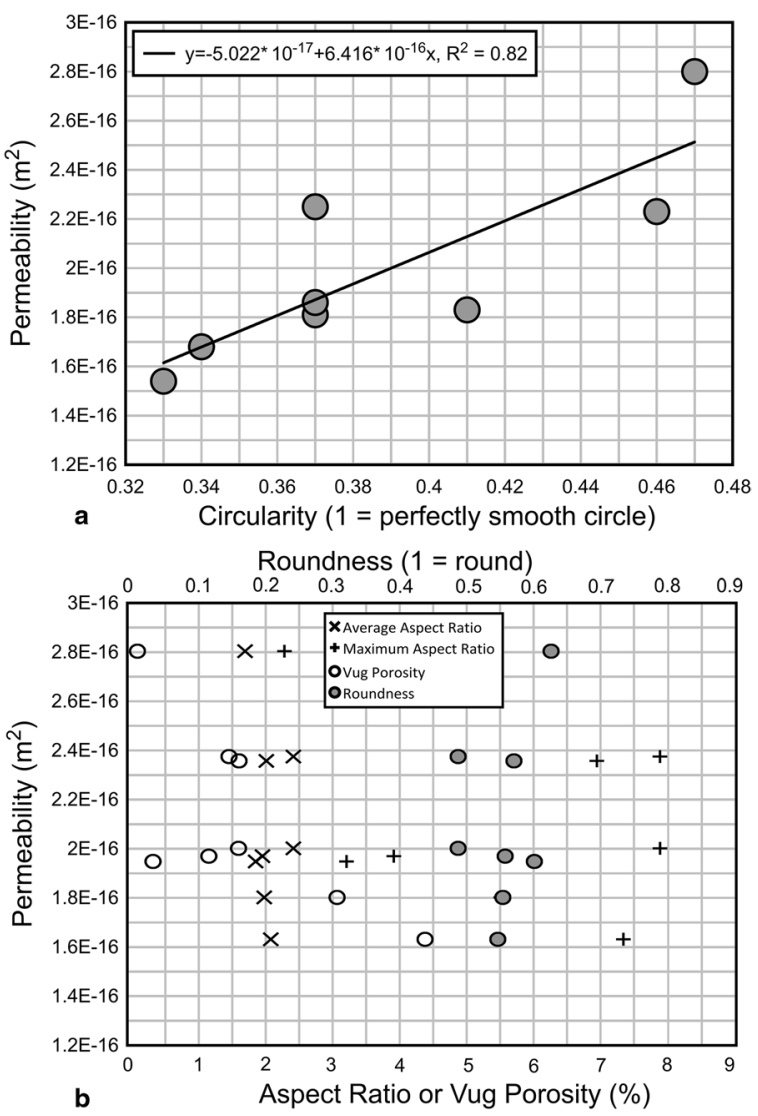

Fig. 6 Pore geometry measurements versus permeability at $5 \mathrm{MPa}$ confining pressure for pore-dominated samples from NM 11 at 2083-2087.4 m depth. a circularity correlates with permeability; b aspect ratio, roundness, and vug porosity do not correlate with permeability

Table 3 Quantitative analysis of thin sections with microfractures

\begin{tabular}{llclll}
\hline Sample ID & $\begin{array}{l}\text { Thin sec- } \\
\text { tion \# }\end{array}$ & $\begin{array}{l}\text { Parallel microf- } \\
\text { racture density } \\
\text { per } \mathbf{m m}(\boldsymbol{P} \boldsymbol{\|})\end{array}$ & $\begin{array}{l}\text { Perpendicular } \\
\text { microfracture density } \\
\text { per } \mathbf{m m}(\boldsymbol{P} \perp)\end{array}$ & $\begin{array}{l}\text { Microfracture area } \\
\text { per unit volume }\left(\boldsymbol{S}_{\mathbf{v}}\right) \\
\left(\mathbf{m m}^{\mathbf{2}} \mathbf{\mathbf { m m } ^ { 3 }}\right)\end{array}$ & $\begin{array}{l}\text { Anisotropy } \\
\left(\boldsymbol{\Omega}_{\mathbf{2}, 3}\right)\end{array}$ \\
\hline NM8a 2525.5 B & TS2 & 2.66 & 0.77 & 4.51 & 0.66 \\
NM4 1477.2 A & TS13 & 4.67 & 2.00 & 8.19 & 0.51 \\
NM8a 3284.7 C & TS14 & 16.59 & 13.30 & 31.77 & 0.16 \\
NM8a 3280 C & TS15 & 10.74 & 25.94 & 28.00 & 0.85 \\
NM2 1354.2 B & TS17 & 10.24 & 9.06 & 19.97 & 0.09 \\
NM3 1743 A & TS19 & 4.67 & 4.64 & 9.32 & 0.00 \\
NM3 1743 C & TS20 & 1.10 & 1.29 & 2.28 & 0.13 \\
\hline
\end{tabular}

factors ranging from 0.00 (isotropic, equal number of microfracture intercepts on predetermined $x / y$ planes) to 0.85 (fairly anisotropic, significantly more microfracture intercepts on one plane). As with the pore-dominated samples, the permeability at the lowest confining pressure (5 MPa) was used to compare to the microfracture analysis, which was conducted at atmospheric pressure. There was no clear correlation between microfracture density and connected porosity (Fig. 7a) or permeability (Fig. 7b). 

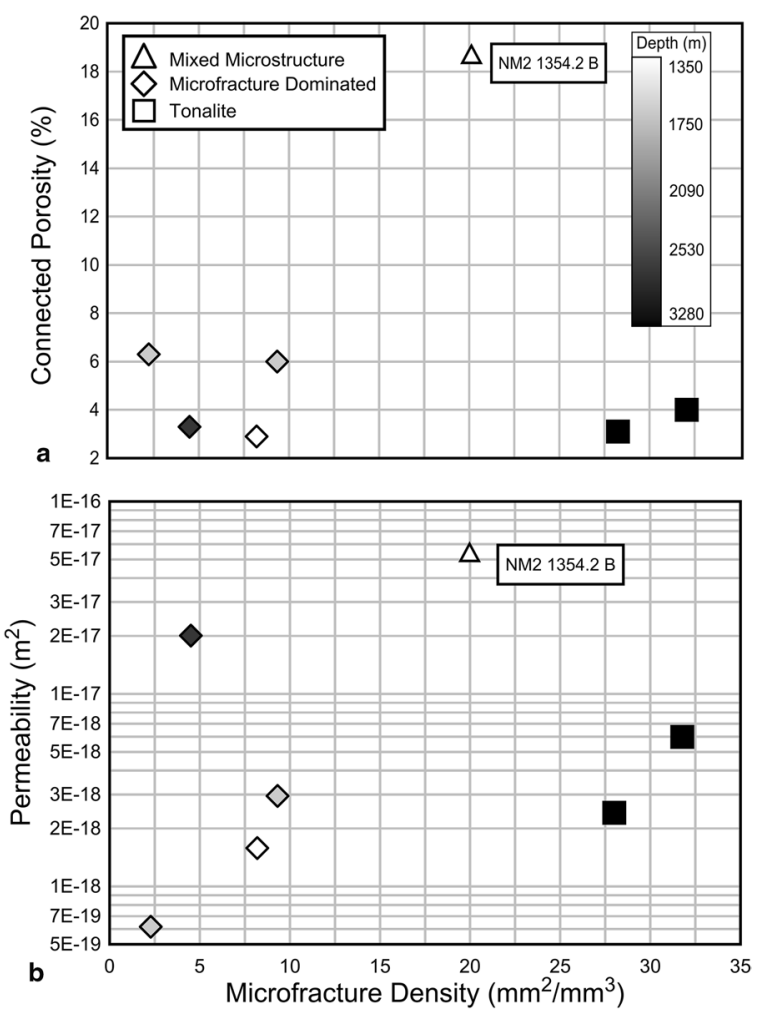

Fig. 7 a connected porosity versus microfracture density. NM2 1354.2 B appears as an outlier with a distinctively higher connected porosity; b permeability at $5 \mathrm{MPa}$ versus microfracture density, using a log scale. NM2 1354.2 B appears as an outlier with a distinctively higher permeability. Tone darkens with depth of sample, as shown in legend

The mixed microfracture and pore samples are not plotted in Figs. 6 or 7, except for NM2 1354.2 B, which plots as an outlier in Fig. 7, because its mixed microstructure made it difficult to define either the circularity or the microfracture density to the same extent as the single microstructure samples.

\section{Physical properties}

There is a clear relationship between connected porosity and dry bulk density (Table 4, Fig. 8), as well as P-wave velocity (Fig. 9). Ultrasonic wave velocity for both saturated and oven dried samples and the calculated dynamic elastic moduli are given in Appendix. Water-saturated samples have a faster P-wave velocity by an average of $147 \mathrm{~m} / \mathrm{s}$ and a slower S-wave velocity by an average of $35 \mathrm{~m} / \mathrm{s}$. Appendix contains the Klinkenberg corrected permeability for all samples tested in this study.

Figure 10 shows the permeability of each sample as a function of confining pressure. Figure 11 shows the connected porosity-permeability relationship according to the microstructure type with each sample tested at the lowest confining pressure (5 MPa) and at the highest confining pressure (55 MPa). The volcaniclastic samples have a wide range of both connected porosity and permeability. The shallow samples with mixed microstructure (Fig. 5a, b) have relatively high permeability and a wide range of (20$21 \%)$ connected porosity. The intermediate connected porosity (12-15\%) samples from intermediate depths (2083-2087 m) and dominated by pore porosity (Fig. 5c, d) have the 
Table 4 Sample cores and their associated sample ID [consisting of well number (NM\#), depth and sample \#], formation name, microstructure type, dry bulk density, and connected porosity

\begin{tabular}{|c|c|c|c|c|}
\hline $\begin{array}{l}\text { Sample ID (well \#, } \\
\text { depth, sample) }\end{array}$ & $\begin{array}{l}\text { Formation } \\
\text { name }\end{array}$ & Microstructure type & $\begin{array}{l}\text { Dry bulk density } \\
\left(\mathrm{kg} / \mathrm{m}^{3}\right)\end{array}$ & $\begin{array}{l}\text { Connected } \\
\text { porosity (\%) }\end{array}$ \\
\hline NM2 1354.2 A & Tahorakuri & Mixed pores and microfractures & 2070 & 20.3 \\
\hline NM2 1354.2 B & Tahorakuri & Mixed pores and microfractures & 2100 & 18.6 \\
\hline NM2 1354.4 A & Tahorakuri & Mixed pores and microfractures & 2160 & 19.3 \\
\hline NM2 $1788 \mathrm{~A}$ & Tahorakuri & Mixed pores and microfractures & 2470 & 10.0 \\
\hline NM2 2254.7 A & Tahorakuri & Microfracture dominated & 2570 & 4.9 \\
\hline NM3 $1743 \mathrm{~A}$ & Tahorakuri & Microfracture dominated & 2540 & 6.0 \\
\hline NM3 $1743 \mathrm{C}$ & Tahorakuri & Microfracture dominated & 2510 & 6.3 \\
\hline NM4 1477.2 A & Tahorakuri & Microfracture dominated & 2670 & 2.9 \\
\hline NM8a 2525.5 B & Tahorakuri & Microfracture dominated & 2600 & 2.5 \\
\hline NM8a 2525.5 C & Tahorakuri & Microfracture dominated & 2580 & 3.3 \\
\hline NM8a 3280 C & NIC Tonalite & Microfracture dominated & 2510 & 3.1 \\
\hline NM8a 3284.7 C & NIC Tonalite & Microfracture dominated & 2490 & 4.0 \\
\hline NM11 2083 A & Tahorakuri & Pore dominated & 2290 & 14.3 \\
\hline NM11 2083 B & Tahorakuri & Pore dominated & 2270 & 15.3 \\
\hline NM11 2083 C & Tahorakuri & Pore dominated & 2290 & 14.7 \\
\hline NM11 2083.34 A & Tahorakuri & Pore dominated & 2300 & 14.0 \\
\hline NM11 2083.34 B & Tahorakuri & Pore dominated & 2280 & 14.9 \\
\hline NM11 2087.4 A & Tahorakuri & Pore dominated & 2350 & 12.9 \\
\hline NM11 2087.4 B & Tahorakuri & Pore dominated & 2310 & 14.4 \\
\hline NM11 2087.4C & Tahorakuri & Pore dominated & 2320 & 14.2 \\
\hline NM11 2087.4 D & Tahorakuri & Pore dominated & 2340 & 13.4 \\
\hline
\end{tabular}

NIC, Ngatamariki Intrusive Complex

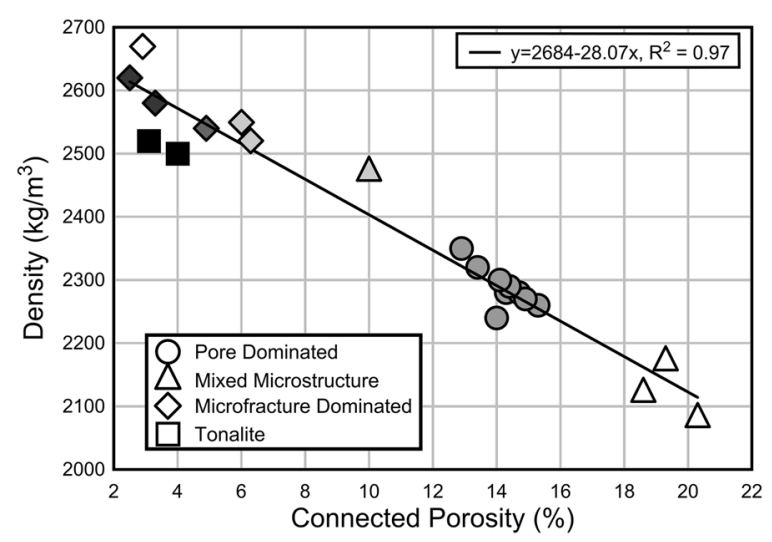

Fig. 8 Dry bulk density versus connected porosity of all samples, by lithology. Tone darkens with depth of sample, as shown in legend in Fig. $7 a$

highest permeability. The volcaniclastic samples with lower connected porosity $(<8 \%)$ and permeability correspond to a microfractured pore structure (Fig. 5e, f), but were sourced from a range of depths. The two samples of tonalite have low connected porosity $(<5 \%)$ and variable permeability; both samples are from great depth and have porosity dominated by microfractures (Fig. $5 \mathrm{~g}, \mathrm{~h}$ ).

Figure 10 also highlights that the four sample types behave in three different ways consistent with their respective microstructure. The volcaniclastic and tonalite samples with 


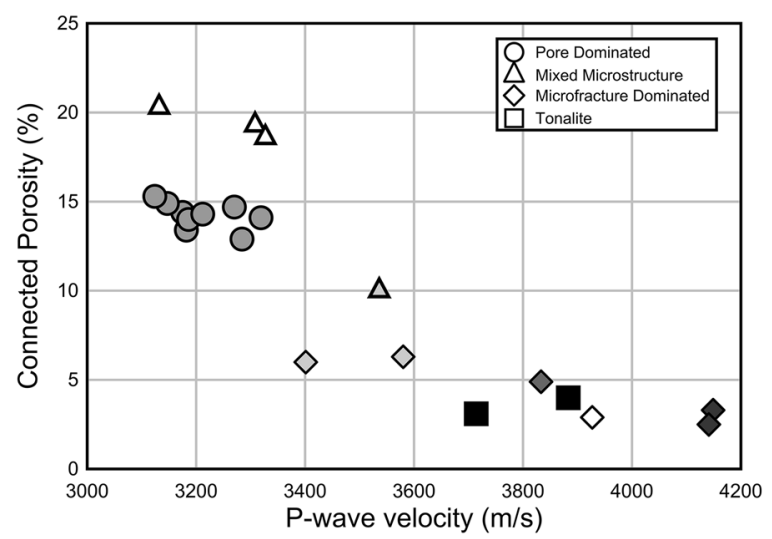

Fig. 9 Dry P-wave velocity versus connected porosity. Tone darkens with depth of sample, as shown in legend in Fig. 7a

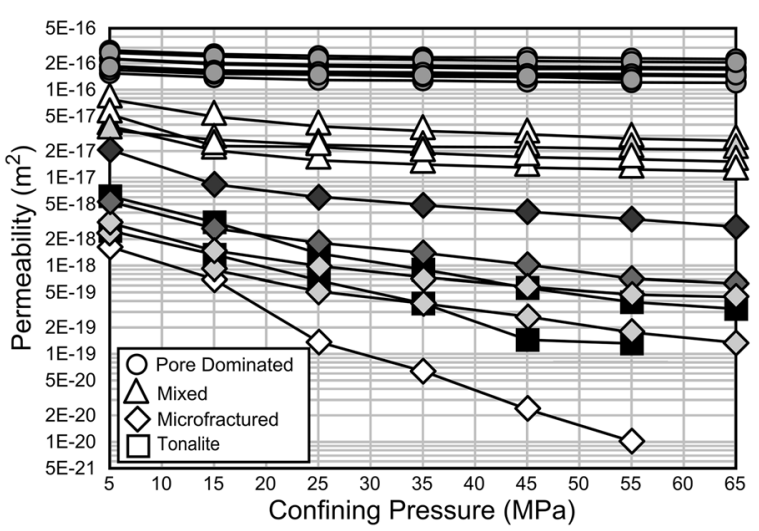

Fig. 10 Permeability versus confining pressure. Tone darkens with depth of sample, as shown in legend in Fig. $7 a$

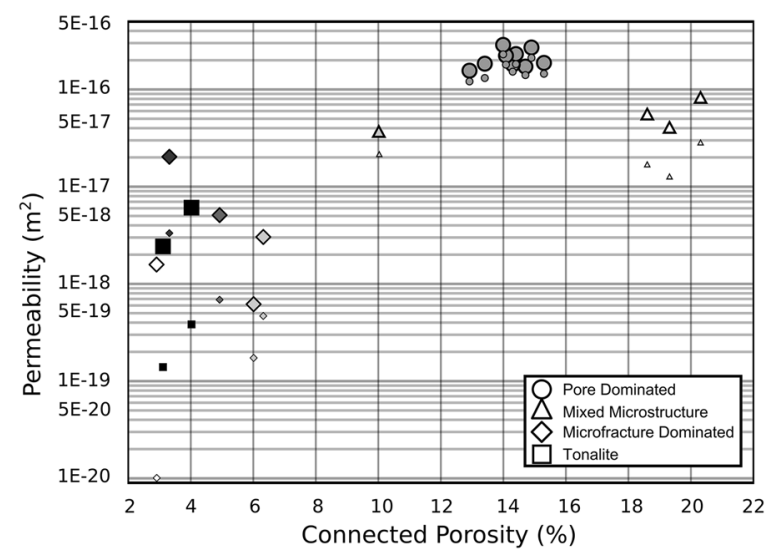

Fig. 11 Permeability versus connected porosity, showing permeability results from both $5 \mathrm{MPa}$ (large symbols) and $55 \mathrm{MPa}$ (small symbols) confining pressures. Tone darkens with depth of sample, as shown in legend in Fig. $7 \mathrm{a}$ 
low, microfracture dominated, porosity experience a relatively large decrease in permeability with increasing confining pressure. The samples with relatively high permeability and with mixed pore and microfracture-dominated microstructure show a small decrease in permeability with increased confining pressure. The samples with pores have a reduced response to increasing confining pressure.

\section{Lithostatic stress model}

Figure 2 shows formation thickness variability across the field. For the Tahorakuri pyroclastic succession, this ranges from $740 \mathrm{~m}$ in NM3 to $1655 \mathrm{~m}$ in NM8a (Chambefort et al. 2014). Table 6 in the Appendix contains the stresses applied by the various formations of the NGF. Table 5 contains the tested samples, their sampling depth, and the corresponding effective lithostatic stress. The in-situ permeability was selected as the permeability at the tested confining stress nearest to the calculated effective lithostatic stress.

\section{Discussion}

\section{Microfracture and pore analysis}

The morphology of primary pores and fractures in an igneous rock is controlled by magma viscosity and gas content, emplacement processes, depositional and tectonic environments (e.g., Lewis and McConchie 1994; Shea et al. 2010; Davidson 2014; Heap et al. 2015; Colombier et al. 2017). The micropore structure, which controls fluid flow (Farquharson et al. 2015; Heap et al. 2017a), can be modified by post-depositional processes. Intrusive rocks have little initial porosity due to their holocrystalline matrix, but

Table 5 Effective lithostatic stress (confining pressure) for each sample with the corresponding permeability test pressure used to calculate the in-situ permeability

\begin{tabular}{llll}
\hline Sample ID & $\begin{array}{l}\text { Effective lithostatic stress } \\
(\mathbf{M P a})\end{array}$ & Tested confining stress $(\mathbf{M P a})$ & In-situ permeability $\mathbf{( m}^{\mathbf{2}} \mathbf{)}$ \\
\hline NM2 1788 A & 18 & 15 & $2.70 \mathrm{E}-17$ \\
NM2 1354.2 A & 12 & 15 & $4.94 \mathrm{E}-17$ \\
NM2 1354.2 B & 12 & 15 & $2.29 \mathrm{E}-17$ \\
NM2 1354.4 A & 12 & 15 & $2.04 \mathrm{E}-17$ \\
NM2 2254.7 & 24 & 25 & $1.76 \mathrm{E}-18$ \\
NM3 1743 A & 17 & 15 & $8.62 \mathrm{E}-19$ \\
NM3 1743 C & 17 & 15 & $8.62 \mathrm{E}-19$ \\
NM4 1477.2 A & 15 & 15 & $6.76 \mathrm{E}-19$ \\
NM8a 2525.5 C & 28 & 25 & $5.80 \mathrm{E}-18$ \\
NM8a 3280 C & 34 & 35 & $3.63 \mathrm{E}-19$ \\
NM8a 3284.7 C & 35 & 35 & $8.74 \mathrm{E}-19$ \\
NM11 2083 A & 21 & 25 & $1.60 \mathrm{E}-16$ \\
NM11 2083 B & 21 & 25 & $1.55 \mathrm{E}-16$ \\
NM11 2083 C & 21 & 25 & $1.49 \mathrm{E}-16$ \\
NM11 2083.34 A & 21 & 25 & $2.43 \mathrm{E}-16$ \\
NM11 2083.34 B & 21 & 25 & $2.26 \mathrm{E}-16$ \\
NM11 2087.4 A & 21 & 25 & $1.29 \mathrm{E}-16$ \\
NM11 2087.4 B & 21 & 25 & $1.92 \mathrm{E}-16$ \\
NM11 2087.4 C & 21 & 25 & $1.85 \mathrm{E}-16$ \\
NM11 2087.4 D & 21 & 25 & $1.48 \mathrm{E}-16$ \\
\hline & & &
\end{tabular}


their post-cooling porosity and permeability develops as a result of tectonic and thermal stresses that manifest as macroscopic and microscopic fractures (Géraud 1994; Lane and Gilbert 2008). Volcanic rocks have a wide range of porosities due to variables such as cooling time, transport, gas content, and weathering (e.g., Mueller et al. 2011; Olalla et al. 2010), while porosity in volcaniclastic and sedimentary rocks is generally controlled by the size and distribution of particles (e.g., Heap et al. 2017a; Bai et al. 2016).

In this study, we attempted to find a correlation between microstructure displayed in $2 \mathrm{D}$ thin sections and physical properties of the sample set. In the pore-dominated samples, only circularity appears to correlate with permeability (Fig. 6). This shows that smooth circular pores conduct fluid better than irregular pores, because for the same pore area, the circular pore will have a smaller amount of pore surface (pore perimeter) at which fluid velocity is 0 . It is interesting that aspect ratio and roundness do not provide a good fit, which suggests that embayments along the pore perimeter do not contribute to fluid flow. This is analogous to the low permeability of some samples with micro-porosity characterised by high surface area in Farquharson et al. (2015), where many micropores did not contribute to fluid flow. We also attempted to determine if a correlation between increased microfracture density and increased connected porosity was present, as has been observed in reservoir rocks of the nearby Rotokawa Andesite (Siratovich et al. 2014). As shown in Fig. 7a, there is no clear correlation between microfracture density and connected porosity in samples with dominant microfractured microstructure. This may be the result of a difference in the microstructure between the two andesites. It could also be that the method used to measure both pore shape and microfracture density only observes these features on a predefined $x$ and $y$ plane (the thin section plane), and does not take into account the depth of pores or the width or length fractures in the third dimension.

To illustrate how small area 2D investigations may yield inaccurate results, we point to sample NM2 $1354.2 \mathrm{~B}$ which displays a connected porosity much higher than would be expected for a sample, whose thin section indicates it only contains microfractures (Fig. 7a). Sample NM2 1354.2 A was extracted from the same piece of core and its thin section does not contain any visible microfractures, but contains several pores. Thin sections from this depth from Wyering (2014), reanalysed for this study, clearly show pores and microfractures (Fig. 5a, b). This illustrates that as shown in Kennedy et al. (2016) when considering the porosity of a system, there is a scale dependence on the structures that control a complicated fluid flow network, and sufficient care is required to ensure statistically relevant volumes.

\section{Ultrasonic wave velocity}

P-wave velocity increases with dry bulk density (Table 4) and decreasing connected porosity (Fig. 9), as also seen in Barton (2007), Vasconcelos et al. (2008), Khandelwal (2013) and Wyering et al. (2014). This shows that the ultrasonic velocity of samples from the Tahorakuri Formation and the Ngatamariki Intrusive Complex are primarily controlled by the connected porosity, and hence the microstructure. The sonic wave results show that the saturated samples have a noticeable P-wave velocity increase (average 4\%) in wave velocity compared to the dry samples, while the saturated and dry S-wave velocities are generally smaller (average $-2 \%$ ). This phenomenon has been observed in other 
studies (e.g., Heap et al. 2013, 2014). The microfracture-dominated samples tended to have a higher dry $\mathrm{P}$ - and $\mathrm{S}$-wave velocities. This is accompanied by greater P-wave velocity increase and smaller S-wave decrease when saturated than the mixed or pore dominated, despite the porosity in pore-dominated samples being much higher. Our data set is too small to provide any statistical quantification of these differences; however, these results demonstrate that sonic wave velocity reduction is less severe in samples with pore dominated compared to microfracture microstructure.

\section{Connected porosity-permeability relationship}

The trend of decreasing permeability with decreasing connected porosity in the NGF rocks shown in Fig. 11 has also been observed in other studies (Heard and Page 1982; Klug and Cashman 1996; Saar and Manga 1999; Rust and Cashman 2004; Stimac et al. 2004; Mueller et al. 2008; Wright et al. 2009; Heap et al. 2014; Farquharson et al. 2015; Wadsworth et al. 2016; Heap and Kennedy 2016). There is scatter in the relationship, which results from the geometry and connectivity of the pores (as noted in Mueller et al. 2008 and others), amongst other factors. The complex geometry of the altered mineralogy, interclast pore spaces, and microfractures, creates highly tortuous flow paths. This is accentuated in the rocks with low connected porosity which, as a result, can be sensitive to confining pressure. Our data set does not contain sufficiently high porosity samples to identify a changepoint in the permeability-porosity relationship similar to the changepoint proposed by Farquharson et al. (2015); however, the critical porosity range of $12-15 \%$ from Heap et al. (2014) and 14-16\% form Farquharson et al. (2015) to some extent captures the distinction between microfracture-dominated and mixed/ pore-dominated microstructure we observe at porosity $>10-12 \%$.

\section{Porosity-permeability relationships and sensitivity to confining pressure}

In this study, our textural analysis shows microfractures and irregular-shaped pores (Fig. 5). As with the previous studies (e.g., Guéguen and Palciauskas 1994; Lamur et al. 2017), these morphologies each react differently to applied confining stresses (Fig. 10). Increasing confining stress causes microfractures to progressively close, resulting in a reduction in permeability (as in Vinciguerra et al. 2005), while elliptical and circular pores show very little change with increased confining stress (Guéguen and Palciauskas 1994; Lamur et al. 2017). Microfracture closure is primarily controlled by elastic deformation, with surface roughness controlling further closure. High aspect ratio microfractures are associated with relatively high permeability at low confining pressures, but are easily closed by increased confining pressures. Conversely to what Vinciguerra et al. (2005) found, we did not find a significant difference in the sensitivity of the fracturedominated samples to confining pressure as a function of their porosity (Fig. 11). The lowest porosity $(\sim 3 \%)$ tonalite and lava have similarly large reductions in permeability between confining pressures of 5 and $55 \mathrm{MPa}$ as the highest porosity lava $(\sim 6 \%)$. Nara et al. (2011) found that samples with low aspect ratio microfractures maintained their influence on permeability even at the highest confining pressure $(90 \mathrm{MPa})$.

To further investigate the effect of confining pressure on permeability, the permeability results at each pressure stage are plotted against confining pressure for all microstructure types (Fig. 10). 
Pore-dominated porosity: From Fig. 10, it is apparent that increasing confining pressure has little effect on the permeability for the majority of the samples. The steepest gradient occurs between 5 and $15 \mathrm{MPa}$ for all samples, with a progressive levelling off of the permeability change with confined pressure. The mixed microstructure samples show a steeper gradient than the pore-dominated samples.

Microfracture porosity: Figure 10 indicates a steeper relationship between increased confining pressure and decreased permeability when compared to the pore-dominated. For most samples, the gradient is steepest at the lower confining pressures $(5-25 \mathrm{MPa})$ with a slightly shallower gradient as the confining pressure increases (25-65 MPa). The volcaniclastic sample with permeability of $9.79 \times 10^{-21} \mathrm{~m}^{2}$ at $55 \mathrm{MPa}$ has a much steeper and more consistently steep gradient than the other samples. This suggests that microstructure continued to be closed as confining pressure increased. A possibility is that the sample is compacting non-elastically during the high confinement; however, Heap et al. (2015) report that triaxial data on $\sim 30 \%$ connected porosity tuff that indicates lower porosity $(<20 \%)$ samples would likely require higher confinement than $55 \mathrm{MPa}$ to initiate permanent compaction. Our preferred explanation is that these fractures in 2D were actually complex dissolution, vein precipitation, and then recrystallised pipes in 3D and thus do not simply close like microfractures. Textures in thin sections (Fig. 5c, d) support a more complex origin for these structures.

The permeability of the lowest and highest confining pressures was used to demonstrate the effect of pore structure on permeability with increased confining pressure. Figure 11 shows that while the tonalite- and microfracture-dominated volcaniclastics were formed by different processes; their porosity, permeability, and response to confining stress are similar. This suggests that similar microstructures can be found across very different lithologies. Some of the mixed microstructure volcaniclastic samples have a higher connected porosity than the pore-dominated samples and yet a lower permeability. Tuff samples in Heap et al. (2017b) showed a large range in permeability depending on grainsize and presence and absence of intergranular pore-filling cement. In general, the volcaniclastic samples form two distinct clusters, one at high connected porosity and permeability and a second at low connected porosity and permeability. However, the limited textural data provided by the small area $2 \mathrm{D}$ thin sections were unable to consistently distinguish distinct microstructures between these groups (e.g., NM2 $1354.2 \mathrm{~B}$ is an outlier in Fig. 7a) and this necessitates reliance upon the sensitivity of the permeability to confining pressure to identify microstructure type.

Figure 11 indicates that for the rocks we tested, relatively low connected porosity generally correlates with samples with microfractures while relatively high connected porosity correlates with those containing pores or mixed microfractures and pores. The low connected porosity samples exhibit a relatively large decrease in permeability with increased confining pressure consistent with the closure of microfractures during elastic deformation, reducing permeability within the sample (e.g., Nara et al. 2011). The elliptical pore structure in the samples in most of the higher connected porosity samples is resistant to closure with increasing confining pressure, resulting in comparatively small decreases in permeability (e.g., Lamur et al. 2017). However, the mixed microstructure samples show a much larger decrease in permeability than the pore-dominated samples. From this observation, we can infer that elastic closure of microfractures is important 
even in samples with high connected porosity. Therefore, we suggest that both microfractures and pores contribute to the permeability such that the control on fluid flow is not mutually exclusive to a single microstructural type, where pores connected by fractures would also be sensitive to confinement. We also emphasize that the microfractures in these altered volcaniclastic rocks are complex with a clear history of both post-fracture dissolution and vein precipitation (Fig. 5).

\section{Effect of increased depth on physical properties}

The microstructural analysis indicates that lithology, burial depth, and hydrothermal alteration need to be considered together when interpreting microstructure. Figure 12 shows that there are large variations in permeability with depth, and when all microstructure types are plotted together, there is no systematic relationship for these rocks. The previous studies have reported systematic changes in physical properties with depth (e.g., Wyering et al. 2014) as a result of different alteration processes. At NGF, increased depth is associated with increased geothermal fluid temperatures (Boseley et al. 2012), and corresponding alteration and changes in mineralogy (e.g., Reyes 1990; Tewhey 1977; Wyering et al. 2014). The Tahorakuri samples have variations in hydrothermally deposited minerals, with the shallow samples showing relatively high zeolite content and the deep samples containing zeolite and epidote (Fig. 5). The shallow units show evidence of both dissolution, resulting in open pores, and microfracturing, dissolution, and veining (Fig. 5a, b). Samples with pore-dominated structures (Table 2) tend to have higher connected porosities $(>10 \%)$ and come from intermediate depths. This is above the silica precipitation depth (Saishu et al. 2014; Wyering et al. 2014) and porosity is the result of extensive dissolution of pumice clasts with the zeolites, epidote, and clay only partially infilling the resulting large, open pores.

Consistent with Wyering et al. (2014) and Chambefort et al. (2014) deeper samples showed that a higher proportion of the thin section contained secondary minerals and re-crystallisation by quartz and feldspar in veins, matrix, and clasts. In the deepest samples, this appeared to reduce the porosity and permeability by cementing microfractures

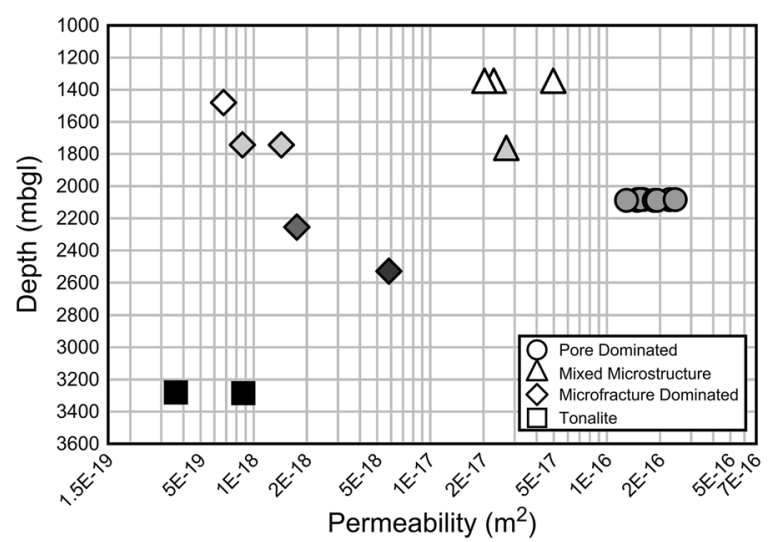

Fig. 12 Depth versus Permeability corrected for lithostatic pressure with lithologies identified. Tone darkens with depth of sample, as shown in legend in Fig. 7a 
(quartz veins in Fig. 5e, f) and filling open pores. The two rock types with low connected porosities $(<8 \%)$ have similar microfracture-dominated pore structures, but come from a range of depths and their microstructure arose from two different origins: (1) the volcaniclastics may have undergone pore collapse and ductile compaction, alteration, dissolution, and re-precipitation of silica (Saishu et al. 2014) leading to a dominantly microfracture-dominated porosity (Siratovich et al. 2016; Wadsworth et al. 2016). (2) The micro-crystalline tonalite may have never formed pores and only developed fractures in response to cooling (Siratovich et al. 2015) or tectonic stresses (Davidson 2014). Figure 8 also highlights that the tonalite does not sit on the same porosity-density trendline as the volcaniclastics, suggesting that while there is evidence of alteration mineralogy in the tonalite (Fig. 5d, e), it is not as intense as for the other lithologies, contributing to its lack of pores. The identified pore structure type (i.e., pores or microfracture) plays a large role in the permeability, with microfractured samples typically having lower permeabilities that are more sensitive to confining pressure than pore-dominated samples (Fig. 11).

The textural differences in the volcaniclastic units prevent a systematic reduction in connected porosity associated with increasing burial depth and alteration. Figure 13 shows the physical properties from the Tahorakuri Formation plotted against depth (note that the values plotted are averaged from the test results). With the microstructure identified, visible groupings of physical properties within each microstructure group become apparent. For example, the microfracture-dominated samples have a relatively low permeability, fast sonic wave velocity, low connected porosity, and high dry bulk density.

Due to limited data and complex interactions between rock properties and postdeposition alteration and mineralization (e.g., Pola et al. 2014; Kanakiya et al. 2017), it is difficult to isolate the effects burial diagenesis (e.g., Wadsworth et al. 2016). In our study, these fluctuations have been attributed to the variations in primary lithological textures and microstructure as well as secondary alteration, dissolution, and re-precipitation. Other studies of burial diagenesis in geothermal systems have observed similar changes in mechanical properties with depth (Tewhey 1977; Stimac et al. 2004; Mielke

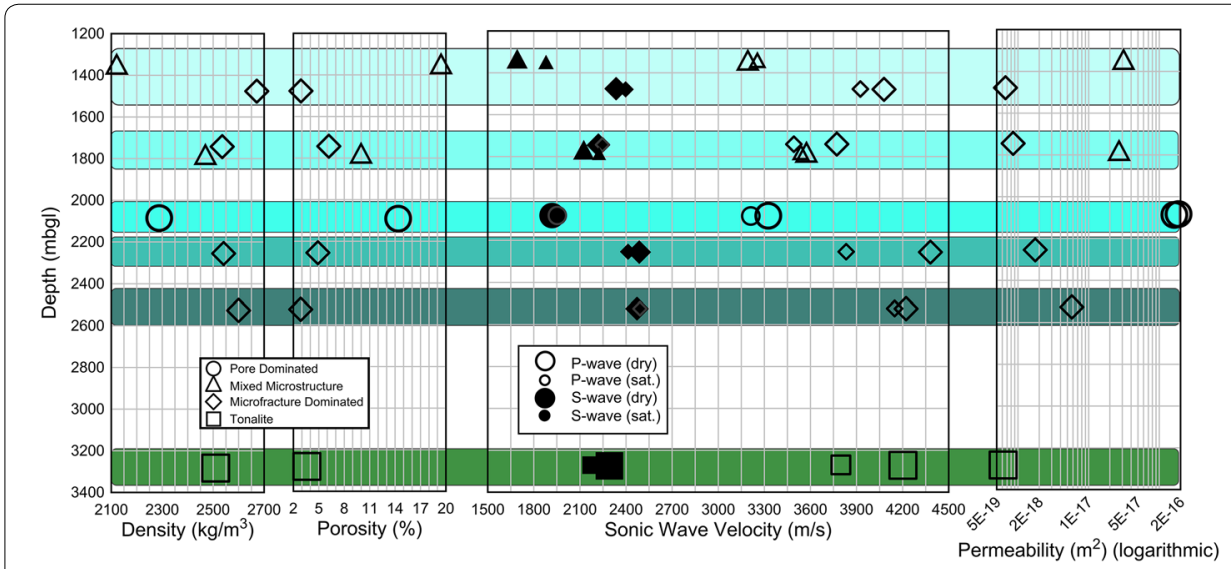

Fig. 13 Indicative mechanical properties of the Tahorakuri Formation (cyan) and the tonalite (green) from the Ngatamariki Igneous Complex arranged by depth. Colours correspond to the colours in Fig. 2 
2009; Dillinger et al. 2014; Wyering et al. 2014, 2015). This shows that while the primary textures of the deposited lithologies must contribute to the effects of burial diagenesis by reducing porosity and increasing density, the hydrothermal alteration plays a much larger role in controlling the physical properties.

\section{Conclusions}

The objective of this paper was to determine the controls on the intact physical properties of a range of volcanic geothermal reservoir rocks. Because the samples were extracted from a range of depths, it was possible to perform permeability testing at confining pressure representative of the in-situ pressure conditions from which they were extracted. Microstructural analysis was performed in conjunction with the physical testing to compare the physical properties to the microstructural textures, mineralogy, and pore structure.

The main conclusions are:

- The physical properties of the tested samples reflect the microstructure types observed. Minor variations within the physical properties are attributed to variations in lithostatic stress and hydrothermal alteration processes. The volcaniclastic units show a large variation in connected porosity, dry bulk density, sonic velocity, permeability, and microstructure, attributed to the compositional range of pumice and lithic components and depositional processes resulting in vastly different primary textures.

- In general, microfracture-dominated samples have lower permeability than poredominated samples. A critical porosity at approximately $10-12 \%$ delineates the changeover from microfracture to pore-dominated permeability and response to confining pressure. However, few consistent correlations exist between the limited 2D thin section analysis-based quantitative microstructure shape and spatial density analysis (e.g., microfracture density) and permeability. Increased pore circularity does weakly correlate with increased permeability, likely as a result of embayments at the pore boundary that do not promote fluid flow, although we emphasize that further analysis on larger 3D volumes (as shown in Kennedy et al. 2016) is required to confirm the correlation.

- Samples with a microfracture pore structure have progressively lower permeability with increased confining pressure when compared to samples with a pore-dominated microstructure. The samples with pore-dominated pore structure show a smaller decrease in permeability with increasing confining pressure compared to the microfractured samples. All samples show the largest decrease occurring between 5 and $15 \mathrm{MPa}$.

- The non-systematic variation in the physical and mechanical properties with depth suggests that lithology, burial diagenesis, and hydrothermal alteration and dissolution all play a role in controlling the physical and mechanical properties of the reservoir rocks. In particular, the variation in the pore structure of lithologies in the Tahorakuri Formation is likely due to variations in sorting and clast density associated with depositional environments. 
- The pore-dominated samples show little decrease in permeability with increased confining pressure and, depending on the effects of alteration, therefore, could retain connected porosity and permeability at great depth $(>3000 \mathrm{~m})$. This then indicates that as long as pore-dominated porosity is preserved, the development of deep geothermal resources may be possible.

Our results show that matrix permeability is not simply a function of lithology, depositional environment, diagenesis, or alteration. It is the combination of all of these that leads to particular microstructure types, each of which contributes to matrix permeability differently. Certain processes tend to occur at specific pressures or temperatures, with different fluids and for different lithologies and primary textures. From a geothermal perspective, this suggests that building a permeability model requires careful geological and physical characterisation of the rock and rock mass for each unique geothermal system. This would also be the case for petroleum reservoirs, dewatering and excavations in volcanic systems or hydrothermally altered systems.

\section{Authors' contributions}

JLC performed the laboratory testing, analysis, and writing of the manuscript. PAS, JWC, MCV, and BMK conceived the project, secured the funding, selected the samples, supervised the research and analysis, and finalised the completion of the manuscript. All authors read and approved the final manuscript.

\section{Acknowledgements}

The authors wish to thank Mercury NZ Limited, Tauhara North No. 2 Trust and Te Pumautanga o Te Arawa Trust for the use of core supplied for this study. The technical staff at the University of Canterbury was invaluable for conducting the laboratory testing.

\section{Competing interests}

The authors declare that they have no competing interests.

Availability of data and materials

The data set supporting the conclusions of this article is included within the article.

\section{Consent for publication}

Not applicable.

Ethics approval and consent to participate

Not applicable.

Funding

This research was funded by Mercury NZ Limited (formerly Mighty River Power).

\section{Appendix}

See Tables 6, 7, and 8 . 
Table 6 Ultrasonic wave velocities and the derived dynamic elastic constants; oven dried and saturated

\begin{tabular}{|c|c|c|c|c|c|c|c|c|}
\hline \multicolumn{5}{|c|}{ Ultrasonic wave velocity (oven dried) } & \multicolumn{4}{|c|}{ Ultrasonic wave velocity (saturated) } \\
\hline Sample ID & $\begin{array}{l}\text { P-wave } \\
\text { velocity } \\
(\mathrm{m} / \mathrm{s})\end{array}$ & $\begin{array}{l}\text { S-wave } \\
\text { velocity } \\
(\mathrm{m} / \mathrm{s})\end{array}$ & $\begin{array}{l}\text { Young } \\
\text { modu- } \\
\text { lus (GPa) }\end{array}$ & $\begin{array}{l}\text { Poisson's } \\
\text { ratio }\end{array}$ & $\begin{array}{l}\text { P-wave } \\
\text { velocity } \\
(\mathrm{m} / \mathrm{s})\end{array}$ & $\begin{array}{l}\text { S-wave } \\
\text { velocity } \\
(\mathrm{m} / \mathrm{s})\end{array}$ & $\begin{array}{l}\text { Young } \\
\text { modulus } \\
(\mathrm{GPa})\end{array}$ & $\begin{array}{l}\text { Poisson's } \\
\text { ratio }\end{array}$ \\
\hline NM2 1354.2 A & 3132 & 1850 & 17.5 & 0.23 & 3038 & 1609 & 14.1 & 0.31 \\
\hline NM2 1354.2 B & 3327 & 1894 & 19.2 & 0.26 & 2975 & 1769 & 16.3 & 0.23 \\
\hline NM2 1354.4 A & 3308 & 1892 & 19.5 & 0.26 & 3568 & 1692 & 16.8 & 0.35 \\
\hline NM2 1788 A & 3536 & 2225 & 28.7 & 0.17 & 3568 & 2122 & 27.3 & 0.23 \\
\hline NM2 2254.7 A & 3833 & 2913 & 35.2 & 0.17 & 4381 & 2484 & 39.6 & 0.26 \\
\hline NM3 1743 A & 3401 & 2238 & 28.6 & 0.12 & 3668 & 2192 & 30.0 & 0.22 \\
\hline NM3 1743 C & 3580 & 2275 & 30.3 & 0.16 & 3873 & 2239 & 31.6 & 0.25 \\
\hline NM4 1477.2 A & 3927 & 2400 & 37.0 & 0.20 & 4077 & 2330 & 36.5 & 0.26 \\
\hline NM8a 2525.5 B & 4141 & 2464 & 39.0 & 0.23 & 4491 & 2543 & 42.8 & 0.26 \\
\hline NM8a 2525.5 C & 4149 & 2488 & 38.9 & 0.22 & 3953 & 2432 & 36.5 & 0.20 \\
\hline NM8a 3280 C & 3714 & 2146 & 29.0 & 0.25 & 3969 & 2346 & 34.2 & 0.23 \\
\hline NM8a 3284.7 C & 3883 & 2180 & 30.2 & 0.27 & 4434 & 2234 & 33.2 & 0.33 \\
\hline NM11 2083 A & 3212 & 1989 & 21.4 & 0.19 & 3287 & 1881 & 20.3 & 0.26 \\
\hline NM11 2083 B & 3124 & 1935 & 20.1 & 0.19 & 3395 & 1872 & 20.3 & 0.28 \\
\hline NM11 2083 C & 3270 & 2057 & 22.6 & 0.17 & 3366 & 1959 & 21.8 & 0.24 \\
\hline NM11 2083.34 A & 3186 & 1887 & 19.6 & 0.23 & 3233 & 1855 & 19.3 & 0.25 \\
\hline NM11 2083.34 B & 3147 & 1947 & 20.5 & 0.19 & 3288 & 1961 & 21.4 & 0.22 \\
\hline NM11 2087.4 A & 3284 & 1967 & 22.2 & 0.22 & 3348 & 1990 & 22.8 & 0.23 \\
\hline NM11 2087.4 B & 3175 & 1914 & 20.4 & 0.21 & 3364 & 1904 & 21.0 & 0.26 \\
\hline NM11 2087.4C & 3319 & 1884 & 20.6 & 0.26 & 3297 & 1902 & 20.8 & 0.25 \\
\hline NM11 2087.4 D & 3182 & 1968 & 21.4 & 0.19 & 3340 & 1963 & 22.1 & 0.24 \\
\hline
\end{tabular}

Table 7 True permeability at confining pressures from 5 to $65 \mathrm{MPa}$ using Klinkenberg correction

\begin{tabular}{|c|c|c|c|c|c|c|c|}
\hline \multirow[t]{2}{*}{ Sample ID } & \multicolumn{7}{|c|}{ Confining pressures (MPa) } \\
\hline & 5 & 15 & 25 & 35 & 45 & 55 & 65 \\
\hline NM2 1354.2 A & $7.80 \mathrm{E}-17$ & $4.94 \mathrm{E}-17$ & $3.83 E-17$ & $3.39 E-17$ & $3.11 \mathrm{E}-17$ & $2.78 \mathrm{E}-17$ & $2.63 E-17$ \\
\hline NM2 1354.2 B & $5.26 \mathrm{E}-17$ & $2.29 \mathrm{E}-17$ & $2.23 \mathrm{E}-17$ & $1.91 \mathrm{E}-17$ & $1.71 \mathrm{E}-17$ & $1.62 \mathrm{E}-17$ & $1.52 \mathrm{E}-17$ \\
\hline NM2 1354.4 A & $3.87 \mathrm{E}-17$ & $2.04 \mathrm{E}-17$ & $1.57 \mathrm{E}-17$ & $1.41 \mathrm{E}-17$ & $1.30 \mathrm{E}-17$ & $1.24 \mathrm{E}-17$ & $1.18 \mathrm{E}-17$ \\
\hline NM2 1788 A & $3.46 \mathrm{E}-17$ & $2.70 \mathrm{E}-17$ & $2.36 \mathrm{E}-17$ & $2.24 \mathrm{E}-17$ & $2.22 \mathrm{E}-17$ & $2.12 \mathrm{E}-17$ & $2.07 \mathrm{E}-17$ \\
\hline NM2 2254.7 A & $5.16 \mathrm{E}-18$ & $2.57 \mathrm{E}-18$ & $1.76 \mathrm{E}-18$ & $1.35 E-18$ & $9.91 \mathrm{E}-19$ & $6.91 \mathrm{E}-19$ & $6.12 \mathrm{E}-19$ \\
\hline NM3 1743 A & $6.17 E-19$ & $8.62 \mathrm{E}-19$ & $4.98 \mathrm{E}-19$ & $3.62 \mathrm{E}-19$ & $2.57 \mathrm{E}-19$ & $1.70 \mathrm{E}-19$ & $1.30 E-19$ \\
\hline NM3 1743 C & $2.95 E-18$ & $1.43 E-18$ & $9.61 \mathrm{E}-19$ & $7.17 \mathrm{E}-19$ & $5.63 E-19$ & $4.58 \mathrm{E}-19$ & $4.29 E-16$ \\
\hline NM4 1477.2 A & $1.58 \mathrm{E}-18$ & $6.76 \mathrm{E}-19$ & $1.32 \mathrm{E}-19$ & $6.16 \mathrm{E}-20$ & $2.27 \mathrm{E}-20$ & $9.79 E-21$ & - \\
\hline NM8a 2525.5 C & $2.01 E-17$ & $8.15 E-18$ & $5.80 \mathrm{E}-18$ & $4.70 \mathrm{E}-18$ & $3.98 \mathrm{E}-18$ & $3.27 E-18$ & $2.68 \mathrm{E}-18$ \\
\hline NM8a 3280 & $2.41 E-18$ & $1.29 E-18$ & $6.59 E-19$ & $3.63 E-19$ & $1.40 E-19$ & $1.27 \mathrm{E}-19$ & - \\
\hline NM8a 3284.1 A & $1.86 \mathrm{E}-16$ & $1.66 \mathrm{E}-16$ & $1.60 E-16$ & $1.57 \mathrm{E}-16$ & $1.52 \mathrm{E}-16$ & $1.51 \mathrm{E}-16$ & $1.48 \mathrm{E}-16$ \\
\hline NM8a 3284.1 B & $1.83 E-16$ & $1.64 \mathrm{E}-16$ & $1.55 E-16$ & $1.51 \mathrm{E}-16$ & $1.47 \mathrm{E}-16$ & $1.45 E-16$ & $1.42 \mathrm{E}-16$ \\
\hline NM8a 3284.1 C & $1.68 \mathrm{E}-16$ & $1.51 \mathrm{E}-16$ & $1.49 E-16$ & $1.41 \mathrm{E}-16$ & $1.39 E-16$ & $1.40 E-16$ & - \\
\hline NM8a 3284.7 C & $5.98 \mathrm{E}-18$ & $3.02 E-18$ & $1.33 \mathrm{E}-18$ & $8.74 \mathrm{E}-19$ & $5.45 E-19$ & $3.76 \mathrm{E}-19$ & $3.15 E-19$ \\
\hline NM11 2083.34 A & $2.80 E-16$ & $2.55 E-16$ & $2.43 E-16$ & $2.34 \mathrm{E}-16$ & $2.33 E-16$ & $2.27 \mathrm{E}-16$ & $2.23 E-16$ \\
\hline NM11 2083.34 B & $2.63 E-16$ & $2.39 E-16$ & $2.26 \mathrm{E}-16$ & $2.19 \mathrm{E}-16$ & $2.13 E-16$ & $2.08 \mathrm{E}-16$ & $2.05 E-16$ \\
\hline NM11 2087.4A & $1.54 \mathrm{E}-16$ & $1.38 \mathrm{E}-16$ & $1.29 E-16$ & $1.27 \mathrm{E}-16$ & $1.23 \mathrm{E}-16$ & $1.21 \mathrm{E}-16$ & $1.20 E-16$ \\
\hline NM11 2087.4 B & $2.25 E-16$ & $2.01 E-16$ & $1.92 \mathrm{E}-16$ & $1.88 \mathrm{E}-16$ & $1.84 \mathrm{E}-16$ & $1.81 \mathrm{E}-16$ & $1.78 \mathrm{E}-16$ \\
\hline NM11 2087.4 C & $2.23 E-16$ & $1.95 E-16$ & $1.85 \mathrm{E}-16$ & $1.79 E-16$ & $1.72 \mathrm{E}-16$ & $1.72 \mathrm{E}-16$ & $1.70 E-16$ \\
\hline NM11 2087.4 D & $1.81 E-16$ & $1.56 \mathrm{E}-16$ & $1.48 \mathrm{E}-16$ & $1.45 \mathrm{E}-16$ & $1.42 \mathrm{E}-16$ & $1.30 E-16$ & - \\
\hline
\end{tabular}

- , not tested 
Table 8 Bulk lithostatic and hydrostatic stress applied to each formation

\begin{tabular}{|c|c|c|c|c|c|c|c|c|c|c|}
\hline \multicolumn{11}{|c|}{ Bulk stress applied by lithostatic pressure and hydrostatic pressure (MPa) } \\
\hline \multirow[t]{2}{*}{ Formation } & \multirow{2}{*}{$\frac{\text { NM2 }}{\text { Litho. }}$} & \multirow[b]{2}{*}{ Hydro. } & \multirow{2}{*}{$\frac{\text { NM3 }}{\text { Litho. }}$} & \multirow[b]{2}{*}{ Hydro. } & \multirow{2}{*}{$\frac{\text { NM4 }}{\text { Litho. }}$} & \multirow[b]{2}{*}{ Hydro. } & \multirow{2}{*}{$\frac{\text { NM8a }}{\text { Litho. }}$} & \multirow[b]{2}{*}{ Hydro. } & \multicolumn{2}{|l|}{ NM11 } \\
\hline & & & & & & & & & Litho. & Hydro. \\
\hline Oruanui & 1.6 & 1.1 & 1.6 & 1.1 & 0.64 & 0.44 & 0.74 & 0.51 & 0.78 & 0.54 \\
\hline Huka falls Fm & 1.6 & 1.5 & 1.6 & 1.5 & 1.5 & 1.5 & 1.7 & 1.7 & 1.8 & 1.7 \\
\hline Rhyolite & 2.9 & 1.6 & 5.4 & 3.0 & 4.3 & 2.4 & 1.3 & 0.74 & 2.9 & 1.6 \\
\hline Waiora Fm & 0.73 & 0.34 & & & 4.5 & 2.1 & 1.8 & 0.83 & 3.9 & 0.18 \\
\hline $\begin{array}{l}\text { Whakamaru group } \\
\text { ignimbrite }\end{array}$ & 4.0 & 2.0 & 2.1 & 1.0 & 3.6 & 1.8 & 6.5 & 3.2 & 1.1 & 5.6 \\
\hline $\begin{array}{l}\text { Tahorakuri sedimentary } \\
\text { succession }\end{array}$ & 7.0 & 3.6 & 6.2 & 3.2 & 2.3 & 1.2 & 6.9 & 3.5 & 4.8 & 2.5 \\
\hline Tahorakuri quartz-rhyolite & 1.6 & 6.9 & 4.1 & 1.8 & 4.1 & 1.8 & & & & \\
\hline $\begin{array}{l}\text { Tahorakuri pyroclastic } \\
\text { succession }\end{array}$ & 25 & 11 & 17 & 7.3 & 23 & 9.6 & 38 & 16 & 28 & 12 \\
\hline $\begin{array}{l}\text { Tahorakuri volcaniclastic } \\
\text { andesite breccia }\end{array}$ & 1.3 & 0.54 & & & & & 2.5 & 1.0 & & \\
\hline $\begin{array}{l}\text { Tahorakuri volcaniclastic } \\
\text { andesite breccia }\end{array}$ & 3.3 & 1.3 & & & & & & & & \\
\hline $\begin{array}{l}\text { Porphyritic microdiorite- } \\
\text { diorite }\end{array}$ & & & & & & & 3.9 & 1.4 & & \\
\hline Quartz-bearing diorite & & & & & & & 5.8 & 2.1 & & \\
\hline Tonalite & & & & & & & 11 & 4.5 & & \\
\hline
\end{tabular}

\section{Publisher's Note}

Springer Nature remains neutral with regard to jurisdictional claims in published maps and institutional affiliations.

Received: 25 October 2017 Accepted: 29 December 2017

Published online: 22 January 2018

\section{References}

Bai H, Pecher IA, Adam L, Field B. Possible link between weak bottom simulating reflections and gas hydrate systems in fractures and macropores of fine-grained sediments: results from the Hikurangi margin, New Zealand. Mar Pet Geol. 2016;71:225-37.

Barton N. Rock quality, seismic velocity, attenuation and anisotropy. London: Taylor \& Francis; 2007.

Bibby HM, Caldwell TG, Davey FJ, Webb TH. Geophysical evidence on the structure of the Taupo Volcanic Zone and its hydrothermal circulation. J Volcanol Geotherm Res. 1995;68(1-3):29-58.

Bignall G. Ngatamariki geothermal field geoscience overview. GNS Sci Consult Rep. 2009;94:41.

Boseley C, Bignall G, Rae AJ, Chambefort I, Lewis B. Stratigraphy and hydrothermal alteration encountered by monitor wells completed at Ngatamariki and Orakei Korako in 2011. In: Proceedings, New Zealand geothermal workshop. 2012. p. 8.

Brace WF, Walsh JB, Frangos WT. Permeability of granite under high pressure. J Volcanol Geotherm Res. 1968;73(6):2225-36

Cant JL. Matrix permeability of reservoir rocks, Ngatamariki geothermal field, Taupo Volcanic Zone, New Zealand. M.Sc. thesis, University of Canterbury, Christchurch, New Zealand. 2015.

Chambefort I, Lewis B, Wilson CJN, Rae AJ, Coutts C, Bignall G, Ireland TR. Stratigraphy and structure of the Ngatamariki geothermal system from new zircon U-Pb geochronology: implications for Taupo Volcanic Zone evolution. J Volcanol Geotherm Res. 2014;274:51-70.

Colombier M, Wadsworth FB, Gurioli L, Scheu B, Kueppers U, Di Muro A, Dingwell DB. The evolution of pore connectivity in volcanic rocks. Earth Planet Sci Lett. 2017;462:99-109.

Coutts C. Revision of Ngatamariki stratigraphy (unpublished Mighty River Power report). 2013.

Davidson J. The effect of fractures on fluid flow in geothermal systems, Taupo Volcanic Zone, New Zealand. Ph.D. thesis, University of Canterbury. 2014.

Dillinger A, Huddlestone-Holmes CR, Zwingmann H, Ricard L, Esteban L. Impacts of diagenesis on reservoir quality in a sedimentary geothermal play. In: Proceedings, thirty-ninth workshop on geothermal reservoir engineering, Stanford University, Stanford, California. 2014. 
Eastwood AA. The Tahorakuri Formation: investigating the early evolution of the Taupo Volcanic Zone in buried volcanic rocks at Ngatamariki and Rotokawa geothermal fields. M.Sc. thesis, University of Canterbury, Christchurch, New Zealand. 2013.

Farquharson IJ, Heap MJ, Varley N, Baud P, Reuschlé T. Permeability and porosity relationships of edifice-forming andesites: a combined field and laboratory study. JVolcanol Geotherm Res. 2015;297:52-68.

Farrell NJC, Healy D. Anisotropic pore fabrics in faulted porous sandstones. J Struct Geol. 2017. https://doi.org/10.1016/j. jsg.2017.09.010.

Géraud Y. Variations of connected porosity and inferred permeability in a thermally cracked granite. Geophys Res Lett. 1994:21(11):979-82.

Glassley WE. Subsurface fluid flow. Geotherm Energy: CRC Press; 2010. p. 51-67.

Guéguen Y, Palciauskas V. Introduciton to the physics of rocks. Princeton: Princeton University Press; 1994.

Heap MJ, Kennedy BM. Exploring the scale-dependent permeability of fractured andesite. Earth Planet Sci Lett. 2016:447:139-50

Heap MJ, Mollo S, Vinciguerra S, Lavallée Y, Hess KU, Dingwell DB, Baud P, lezzi G. Thermal weakening of the carbonate basement under Mt. Etna volcano (Italy): implications for volcano instability. J Volcanol Geotherm Res. 2013;250:42-60.

Heap MJ, Lavallee Y, Petrakova L, Baud P, Reuschle T, Varley NR, Dingwell DB. Microstructural controls on the physical and mechanical properties of edifice-forming andesites at Volcan de Colima, Mexico. J Geophys Res Solid Earth. 2014;119(B4):2925-63.

Heap MJ, Kennedy BM, Pernin N, Jacquemard L, Baud P, Farquharson J, Scheu B, Lavallée Y, Gilg HA, Letham-Brake M, Mayer K, Jolly AD, Reuschlé T, Dingwell DB. Mechanical behavior and failure modes in the Whakaari (White Island volcano) hydrothermal system, New Zealand. J Volcanol Geotherm Res. 2015;295:26-42.

Heap MJ, Kennedy BM, Farquharson Jl, Ashworth J, Mayer K, Letham-Brake M, Reuschlé T, Gilg HA, Scheu B, Lavallée Y, Siratovich P, Cole J, Jolly AD, Baud P, Dingwell DB. A multidisciplinary approach to quantify the permeability of the Whakaari/White Island volcanic hydrothermal system (Taupo Volcanic Zone, New Zealand). J Volcanol Geotherm Res. 2017a;332:88-108.

Heap MJ, Kushnir ARL, Gilg HA, Wadsworth FB, Reuschlé T, Baud P. Microstructural and petrophysical properties of the Permo-Triassic sandstones (Buntsandstein) from the Soultz-sous-Forêts geothermal site (France). Geotherm Energy. 2017b. https://doi.org/10.1186/s40517-017-0085-9.

Heard HC, Page L. Elastic moduli, thermal expansion, and inferred permeability of two granites to $350^{\circ} \mathrm{C}$ and 55 megapascals. J Geophys Res Solid Earth. 1982;87(B11):9340-8.

Hurst AW, Bibby HM, Robinson R. Earthquake focal mechanisms in the central Taupo Volcanic Zone and their relation to faulting and deformation. NZ J Geol Geophys. 2002;45(4):527-36.

Jafari A, Babadagli T. Effective fracture network permeability of geothermal reservoirs. Geothermics. 2011;40(1):25-38.

Kanakiya S, Adam L, Esteban L, Rowe M, Shane P. Dissolution and secondary mineral precipitation in basalts due to reactions with carbonic acid. J Geophys Res Solid Earth. 2017;122(6):4312-27.

Kennedy BM, Wadsworth FB, Schipper CI, Jellinek MJ, Vasseur J, von Aulock FW, Hess K-U, Russell JK, Lavallée Y, Dingwell DB. Surface tension and gas escape from magma. Earth Planet Sci Lett. 2016:433:116-24.

Khandelwal M. Correlating P-wave velocity with the physico-mechanical properties of different rocks. Pure Appl Geophys. 2013;170(4):507-14.

Klinkenberg $L J$. The permeability of porous media to liquids and gases. API drilling and production practice. New York: American Petroleum Institute; 1941. p. 200-13.

Klug C, Cashman KV. Permeability development in vesiculating magmas: implications for fragmentation. Bull Volcanol. 1996:58:87-100

Lamur A, Kendrick JE, Eggertsson GH, Wall RJ, Ashworth JD, Lavallée Y. The permeability of fractured rocks in pressurised volcanic and geothermal systems. Sci Rep. 2017;7(1):6173.

Lane SJ, Gilbert JS. Fluid motions in volcanic conduits: a source of seismic and acoustic signals. London: Geological Society Publishing House; 2008.

Lewis DW, McConchie D. Practical sedimentology. 2nd ed. New York: Chapman \& Hall; 1994.

MBIE. Energy in New Zealand, 2016 calendar year edition. Ministry of business, innovation and employment. Crown Copyright 2017. Wellington, New Zealand. 2017. ISSN 2324-5319.

Mielke P. Properties of the reservoir rocks in the geothermal field of Wairakei, New Zealand. Ph.D. thesis, Technische Universität Darmstadt. 2009.

Mueller S, Scheu B, Spieler O, Dingwell DB. Permeability control on magma fragmentation. Geology. 2008;36:399-402.

Mueller S, Scheu B, Kueppers U, Spieler O, Richard D, Dingwell DB. The porosity of pyroclasts as an indicator of volcanic explosivity. J Volcanol Geotherm Res. 2011;203(3):168-74.

Murphy H, Huang C, Dash Z, Zyvoloski G, White A. Semianalytical solutions for fluid flow in rock joints with pressuredependent openings. Water Resour Res. 2004;40(12):W12506.

Nara Y, Meredith PG, Yoneda T, Kaneko K. Influence of macro-fractures and micro-fractures on permeability and elastic wave velocities in basalt at elevated pressure. Tectonophysics. 2011;503(1-2):52-9.

Olalla C, Hernandez LE, Rodriguez-Losada JA, Perucho Á, González-Gallego J. Volcanic rock mechanics: rock mechanics and geo-engineering in volcanic environments. Boca Raton: CRC Press; 2010.

Peacock DCP, Anderson MW, Rotevatn A, Sanderson DJ, Tavarnelli E. The interdisciplinary use of "overpressure". J Volcanol Geotherm Res. 2017;341:1-5.

Pola A, Crosta GB, Fusi N, Castellanza R. General characterization of the mechanical behaviour of different volcanic rocks with respect to alteration. Eng Geol. 2014;169:1-13.

Reyes AG. Petrology of Philippine geothermal systems and the application of alteration mineralogy to their assessment. J Volcanol Geotherm Res. 1990;43(1-4):279-309.

Ruddy I, Andersen MA, Pattillo PD, Bishlawi M, Foged N. Rock compressibility, compaction, and subsidence in a highporosity chalk reservoir: a case study of Valhall field. J Pet Technol. 1989;41(07):741-6. 
Rust AC, Cashman KV. Permeability of vesicular silicic magma: inertial and hysteresis effects. Earth Planet Sci Lett. 2004;228(1-2):93-107.

Saar MO, Manga M. Permeability-porosity relationship in vesicular basalts. Geophys Res Lett. 1999;26:111-4.

Saishu H, Okamoto A, Tsuchiya N. The significance of silica precipitation on the formation of the permeable-impermeable boundary within Earth's crust. Terra Nova. 2014;26:253-9.

Shea T, Houghton BF, Gurioli L, Cashman KV, Hammer JE, Hobden BJ. Textural studies of vesicles in volcanic rocks: an integrated methodology. J Volcanol Geotherm Res. 2010;190(3):271-89.

Siratovich PA. Thermal stimulation of the Rotokawa andesite: a laboratory approach. Ph.D. thesis, University of Canterbury, Christchurch, New Zealand. 2014.

Siratovich PA, Heap MJ, Villeneuve MC, Cole JW, Reuschlé T. Physical property relationships of the Rotokawa Andesite, a significant geothermal reservoir rock in the Taupo Volcanic Zone, New Zealand. Geotherm Energy. 2014;2:10.

Siratovich PA, Villeneuve MC, Cole JW, Kennedy BM, Bégué F. Saturated heating and quenching of three crustal rocks and implications for thermal stimulation of permeability in geothermal reservoirs. Intern J Rock Mech Min Sci 2015;80:265-80

Siratovich P, Heap MJ, Villeneuve MC, Cole JW, Kennedy BM, Davidson J, Reuschle T. Mechanical behaviour of the Rotokawa Andesites (New Zealand): insight into permeability evolution and stress-induced behaviour in an actively utilised geothermal reservoir. Geothermics. 2016;64:163-79.

Stimac JA, Powell TS, Golla GU. Porosity and permeability of the Tiwi geothermal field, Philippines, based on continuous and spot core measurements. Geothermics. 2004;33(1-2):87-107.

Tewhey JD. Geologic characteristics of a portion of the Salton Sea geothermal field. Davis: Geothermal Resource Council; 1977.

Ulusay R, Hudson JA. The complete ISRM suggested methods for rock characterization, testing and monitoring: 1974-2006. In: Ulusay R, Hudson J, editors. Commission on testing methods, International Society of Rock Mechanics. Ankara: IRSM Turkish National Group; 2007.

Underwood EE. Stereology, or the quantitative evaluation of microstructures. J Microsc. 1969;89(2):161-80.

Vasconcelos G, Lourenço PB, Alves CAS, Pamplona J. Ultrasonic evaluation of the physical and mechanical properties of granites. Ultrasonics. 2008;48(5):453-66.

Vinciguerra S, Trovato C, Meredith PG, Benson PM. Relating seismic velocities, thermal cracking and permeability in Mt. Etna and Iceland basalts. Int J Rock Mech Min Sci. 2005;42(7):900-10.

Wadsworth FB, Vasseur J, Scheu B, Kendrick JE, Lavallée Y, Dingwell DB. Universal scaling of fluid permeability during volcanic welding and sediment diagenesis. Geology. 2016;44:219-22.

Watson A. Geothermal engineering: fundamentals and applications. 1st ed. Dordrecht: Springer; 2013.

Wilson CJN, Rowland JV. The volcanic, magmatic and tectonic setting of the Taupo Volcanic Zone, New Zealand, reviewed from a geothermal perspective. Geothermics. 2016;59:168-87.

Wilson CJN, Houghton BF, McWilliams MO, Lanphere MA, Weaver SD, Briggs RM. Volcanic and structural evolution of Taupo Volcanic Zone, New Zealand: a review. J Volcanol Geotherm Res. 1995;68(1-3):1-28.

Wright HMN, Cashman KV, Gottesfeld EH, Roberts JJ. Pore structure of volcanic clasts: measurements of permeability and electrical conductivity. Earth Planet Sci Lett. 2009;280:93-104.

Wu XY, Baud P, T-f Wong. Micromechanics of compressive failure and spatial evolution of anisotropic damage in Darley Dale sandstone. Int J Rock Mech Min Sci. 2000;37(1):143-60.

Wyering LD. The influence of hydrothermal alteration and lithology on rock properties from different geothermal fields with relation to drilling. Ph.D. thesis, University of Canterbury, Christchurch, New Zealand. 2014.

Wyering LD, Villeneuve MC, Wallis IC, Siratovich PA, Kennedy BM, Gravley DM, Cant JL. Mechanical and physical properties of hydrothermally altered rocks, Taupo Volcanic Zone, New Zealand. J Volcanol Geotherm Res. 2014;288:76-93.

Wyering LD, Villeneuve MC, Wallis IC, Siratovich PA, Kennedy BM, Gravley DM. The development and application of the alteration strength index equation. Eng Geol. 2015;199:48-61.

\section{Submit your manuscript to a SpringerOpen ${ }^{\circ}$ journal and benefit from:}

- Convenient online submission

- Rigorous peer review

- Open access: articles freely available online

- High visibility within the field

Retaining the copyright to your article

Submit your next manuscript at $\boldsymbol{\nabla}$ springeropen.com 